Australian

National

University

Crawford School of Public Policy

Centre for Climate Economics and Policy

\title{
Adoption of solar and wind energy: The roles of carbon pricing and aggregate policy support
}

\section{CCEP Working Paper 1803}

\section{February 2018}

\section{Rohan Best}

Crawford School of Public Policy, The Australian National University rohan.best@anu.edu.au

\section{Paul J. Burke}

Crawford School of Public Policy, The Australian National University paul.j.burke@anu.edu.au

\begin{abstract}
This paper analyzes the roles of policies and preferences in national adoption of solar and wind energy technologies. We use cross-sectional and panel regressions for both the European Union and a broader international sample. We find that countries that price carbon emissions have gone on to adopt more solar and wind energy. The aggregate level of policy support, measured in euros per megawatt hour, appears to have been important for solar energy adoption. We also find that solar energy adoption has been larger in countries with higher proportions of people concerned about climate change. In addition, we assess the effects of other key explanators including financial system size and income levels.
\end{abstract}




\section{Key words:}

Solar energy; wind energy; carbon pricing; aggregate policy support; renewable energy preference; climate change perception

\section{JEL codes:}

Q40; Q42; Q48

\section{Suggested Citation:}

Best, R. and Burke, P. J. (2018), Adoption of solar and wind energy: The roles of carbon pricing and aggregate policy support. CCEP Working Paper 1803, Feberuary 2018. Crawford School of Public Policy, The Australian National University.

\section{Address for Correspondence:}

Rohan Best

Arndt-Corden Department of Economics

Crawford School of Public Policy

The Australian National University

rohan.best@anu.edu.au

The Crawford School of Public Policy is the Australian National University's public policy school, serving and influencing Australia, Asia and the Pacific through advanced policy research, graduate and executive education, and policy impact.

The Centre for Climate Economics \& Policy is an organized research unit at the Crawford School of Public Policy, The Australian National University. The working paper series is intended to facilitate academic and policy discussion, and the views expressed in working papers are those of the authors. Contact for the Centre: Dr Frank Jotzo, frank.jotzo@anu.edu.au 


\section{ENERGY TRANSITION \\ HO innovation partnership}

\section{Adoption of solar and wind energy: The roles of carbon pricing and aggregate policy support}

Rohan Best and Paul J. Burke

Crawford School of Public Policy, Australian National University, Acton ACT 2601, Australia

February 2018

This paper analyzes the roles of policies and preferences in national adoption of solar and wind energy technologies. We use cross-sectional and panel regressions for both the European Union and a broader international sample. We find that countries that price carbon emissions have gone on to adopt more solar and wind energy. The aggregate level of policy support, measured in euros per megawatt hour, appears to have been important for solar energy adoption. We also find that solar energy adoption has been larger in countries with higher proportions of people concerned about climate change. In addition, we assess the effects of other key explanators including financial system size and income levels.

Acknowledgements: Funding was received from the Department of Foreign Affairs and Trade through the Australian-German Energy Transition Hub, the Australian Research Council (DE160100750), and an Australian Government Research Training Program (RTP) Scholarship. 


\section{Introduction}

Rapid cost reductions mean that solar and wind are likely to play an increasingly important role in the world's future energy system. For example, modelling suggests that it would be feasible for solar photovoltaics and wind to contribute around 90 percent of annual electricity demand in the Australian National Electricity Market (Blakers et al., 2017), with hydroelectricity and biomass providing the remainder.

A key advantage of solar and wind energy is that they avoid carbon dioxide emissions. This provides an opportunity for energy system transformation to make a major contribution to the climate change mitigation goal of keeping anthropogenic global warming below two degrees Celsius (DDPP, 2015; OECD/IEA and IRENA, 2017). An increase in renewable energy share can also help to reduce local pollution, diversify energy mixes, and ameliorate energy security risks arising from reliance on fossil fuels sourced from geopolitically unstable countries.

Increasing reliance on solar and wind energy also comes with challenges, although these are surmountable. One is that solar and wind face intermittency issues without adequate storage solutions or the use of other dispatchable energy sources. Frequency disturbances, when there is insufficient inertia in electricity systems, can also be important to manage. Solar and wind energy sources have been more costly than established energy sources until recently (IEA, 2015; IEA, 2016). This has motivated policy intervention, which has then provided a favourable environment for cost reductions through learning-by-doing.

There is considerable variation in renewable energy adoption across countries. For instance, Denmark has high levels of wind energy use, but combined solar and wind energy use per capita was between 10 and 40 times lower in five other European Union (EU) countries in 2015. Germany had solar energy use per capita that was between 20 and 120 times greater than five other EU countries in 2015, including some with more abundant sunshine.

This paper examines the factors that have been important for the early adoption of solar and wind energy. We consider many variables that could potentially be relevant, including policies, preferences, and access to domestic finance. We use cross-sectional and panel regression approaches for renewable energy adoption up to 2015 for two groups of countries: a group of EU countries, and a larger international sample. The advantages of solar and wind energy provide strong motivation for our study. The paper furthers understanding of the 
factors that promote solar and wind energy and whether frequently-recommended policies have been associated with successful outcomes.

The paper makes a number of contributions relative to the existing literature. We separately consider solar photovoltaic (PV), solar thermal, and wind energy adoption, identifying the factors that have been important for the adoption of each energy type. We give focus to the role of carbon pricing, an efficient policy approach that has not received as much attention in the empirical literature as other policies such as feed-in tariffs or renewable energy certificates. Another key feature of our approach is our use of a cardinal, holistic policy support variable from an Ecofys (2014) report on subsidies and costs of energy for the European Commission. We refer to this variable as aggregate policy support.

The paper proceeds as follows. Section 2 reviews the previous literature. Section 3 explains our method and data. The results are presented in section 4. Section 5 provides some brief case studies. The final section concludes.

\section{Literature review}

\subsection{Current methodologies in the literature explaining solar and wind energy use}

There are many previous studies using various panel regression approaches to assess the determinants of renewable energy use. Zhao et al. (2013) used the Poisson pseudo-maximum likelihood estimation technique for a global panel, finding that renewable electricity policies are important in promoting renewable electricity use. Carley (2009) found that renewable portfolio standard implementation is not a significant predictor of the renewable electricity share of total generation of US states from 1998-2006, based on fixed effects vector decomposition estimates. Pfeiffer and Mulder (2013) used a two-stage approach to separately consider the adoption of and quantity of renewable energy used by a panel of developing countries. Basher et al. (2015) note that the renewable energy share of electricity generation is not stationary in many OECD countries, which poses a challenge for empirical studies that focus on time-series variation.

Survey-based techniques have also been used to assess renewable energy deployment. For example, Friebe et al. (2014) used a qualitative approach to identify key factors for project investment decisions on wind farms and then use a quantitative survey approach ("maximum difference scaling") to further evaluate the importance of these key factors. Eleftheriadis and Anagnostopoulou (2015) surveyed renewable energy experts to identify barriers to renewable 
energy diffusion. Murakami et al. (2015) used a choice experiment to quantify the willingness to pay for renewable electricity by US and Japanese consumers.

Simulation models and scenario analysis are other alternatives. Hirth and Steckel (2016), for example, use a techno-economic power system model to show the combined effect of the weighted average cost of capital and carbon prices on the renewable energy share.

\subsection{Factors that may affect early adoption of solar and wind energy}

Policymakers could theoretically use one policy instrument to target the adoption of renewable energy. In practice, multi-dimensional policy approaches are often employed. Jaffe et al. (2005) note that the interaction of combined market failures associated with pollution externalities and diffusion of new technologies provides a rationale for a portfolio of public policies that aids adoption of environmentally beneficial technology. Sener and Fthenakis (2014) discuss the need for a holistic approach to policy for large-scale solar PV in the United States. We use an aggregate policy support variable from a report by Ecofys (2014) for the European Commission, as described in section 3, to account for aggregate policy support in multi-dimensional policy frameworks. We expect that the aggregate policy support variable has had a positive impact on renewable energy use.

Our use of an aggregate policy variable complements prior studies that focus on specific policies. Using an instrumental variables approach, Smith and Urpelainen (2014) find that feed-in tariffs have been effective in increasing renewable electricity take-up. Baldwin et al. (2016) find that renewable electricity policy impacts differ by country income group. Polzin et al. (2015) note that feed-in tariffs are more effective for less mature technologies, whereas renewable portfolio standards appear more effective for mature technologies. Policies are not always successful; Aguirre and Ibikunle (2014) conclude that policies involving voluntary participation appear to have a negative relationship with renewable energy investment, possibly as a result of uncertainty over government policy changes. Studies also find mixed results depending on the type of policy support. Pfeiffer and Mulder (2013) show negative impacts of institutional and strategic policy support measures from the IEA/IRENA Global Renewable Energy Policies and Measures Database, but positive impacts from economic and regulatory instruments.

Carbon pricing is another specific policy that could influence renewable energy adoption. Carbon pricing can promote cost-effective emissions abatement by providing incentives for private agents to exploit low-cost abatement opportunities (Aldy and Stavins, 2012). A 
carbon price gives producers and consumers an incentive to consider the external costs that their emissions impose on others, promoting socially-efficient resource allocation by addressing the market failure resulting from these externalities. The idea of charging agents for the external costs that they impose on others dates back to Arthur Pigou in the early $20^{\text {th }}$ century (Mankiw, 2009). More recently, there has been a growing number of carbon pricing initiatives around the world, and plans for more (Hepburn, 2017). Yet there is a lack of empirical studies assessing the impact of carbon pricing on renewable energy adoption. For instance, the paper by Basher et al. (2015) includes a table (Table 1) that summarizes empirical studies on the impact of policy on renewable energy diffusion. The table mentions feed-in tariffs and renewable portfolio standards, but not carbon pricing. We expect a positive impact of carbon pricing on renewable energy use, as carbon pricing provides an advantage to renewables by making fossil-fuel alternatives more costly.

Various aspects of governance could be relevant for the adoption of renewable energy. Best and Burke (2017) find that general government effectiveness has been important for electrification in low- and middle-income countries in recent decades, and similar may be true for adoption of modern energy sources. Governments that are more involved in global political processes may also be more likely to promote renewable energy to contribute to international climate goals.

Policy measures focusing on innovation could also affect renewable energy adoption. Countries with a greater focus on innovation could be faster to adopt new technology such as solar energy. Johnstone et al. (2010) show that various policies can spur innovation: feed-in tariffs appear to increase patent numbers for solar, while renewable energy certificates appear to be important for increasing wind energy patent numbers. Popp et al. (2011) analyze the impact of patents on investment in renewable energy capacity and find that technological advances do increase investment to some extent. Together, these two studies indicate that policy can foster innovation, which can increase renewable energy investment. Veugelers (2012) surveys the empirical literature, citing success in environmental policies inducing clean technology innovation, while also noting that there are fewer studies on the adoption of clean technologies.

It may well be the case that there is greater adoption of solar and wind energy when citizens have had stronger preferences for these energy types and when they are more concerned about climate change. This can occur via increased demand for use of these technologies. 
Another mechanism is that stronger preference for renewables may make it less likely that policy support for renewables would be wound back in the future, reducing uncertainty. The negative impact of policy uncertainty on renewable energy investment has been noted for the United States (Barradale, 2010).

We also investigate if the size of financial sectors is important for solar and wind energy adoption. Countries with greater access to financial capital may adopt more capital-intensive energy types such as solar and wind (Brunnschweiler, 2010; Best, 2017; Lin and Omoju, 2017). Larger quantities of financial capital would lower the cost of capital, all else equal, benefitting solar and wind energy generation, which is capital intensive and sensitive to the cost of capital.

Financial sector composition could also be important. The banking sector has been a key source of finance for energy investment in the past (IEA, 2014), but faces financial regulations that discourage long-term energy finance (Kaminker and Stewart, 2012; Ng and Tao, 2016). Private investors, including pension funds, will increasingly be the source of capital for renewable energy due to high government debt in many countries (Della Croce et al., 2011; Kaminker and Stewart, 2012). Corsatea et al. (2014) find that corporate debt is a major factor supporting sales of wind turbines. Equity is typically a smaller component of financial capital than debt for solar and wind projects, with average debt to equity ratios of approximately 70:30 being common (Ecofys, 2017). Further, Best (2017) does not find a significant association between equity and national-level use of solar or wind energy.

Trade could also be important for the dissemination of technology. Omri and Nguyen (2014) find that trade openness is a driver of renewable energy consumption, and Lin and Omoju (2017) find that trade openness has a positive and significant impact on the share of modern renewables. Pfeiffer and Mulder (2013) find a negative relationship between trade intensity and the probability of adopting modern renewables in developing countries.

Natural endowments may also influence the decision to adopt solar and wind technologies. For instance, it seems likely that being blessed with rich wind resources might lead to more uptake of wind energy use, and perhaps less uptake of solar energy technologies, as solar and wind are substitutes. Burke $(2010 ; 2012 ; 2013)$ considers reserves of fossil fuels and the availability of hydro endowments for national uptake of renewables, but did not examine the importance of solar and wind energy resources. The study by Ondraczek et al. (2015), on the other hand, used global horizontal irradiation in explaining solar PV cost. 
Other variables like income and historical national carbon dioxide emission levels could also be important contributors to adoption of solar and wind technologies. Burke (2010) finds that electricity use from different primary energy types follows a national-level ladder with countries progressing to use of different types of energy as per-capita income increases. Solar and wind are on upper rungs of the energy ladder, meaning that their adoption has to date been predominantly by higher income countries. Sadorsky (2009) finds that higher levels of carbon dioxide emissions per capita drive greater subsequent renewable energy consumption in G7 countries, possibly due to increased concern for climate change when emissions are higher.

\subsection{Gaps in the literature}

Previous studies tend to focus on aggregated renewable energy variables. Some split renewable energy into two categories: hydro and non-hydro, while others consider solar and wind separately. Our study is more specific: we separately consider solar PV, solar thermal, and wind energy. It is important to consider energy types separately due to the differences in technology attributes and stage of technology maturity.

Previous regression analysis has commonly focussed on particular polices such as feed-in tariffs and renewable portfolio standards, but often does not consider the overall strength of policy settings. Also, empirical research often does not consider carbon pricing, an important policy that should be likely to affect renewable energy use. We attempt to capture policy effects more comprehensively with a variable for aggregate policy support, and also assess the important carbon pricing variable while controlling for other policies. In addition, we consider factors that make an underlying contribution to the general policy environment: the role of preferences and perceptions, plus general government effectiveness, a factor that can underpin policy formulation and stability.

Prior studies typically focus on temporal variation, using fixed-effects panel regressions. We focus on variation across countries. This is because we are interested in identifying fundamental explanations for why some countries have been more successful in adopting solar and wind technologies than others. 


\section{Method and data}

\subsection{Empirical model}

We focus on using cross-sectional variation to estimate the following model:

$$
T_{c}^{j}=S_{c} \beta^{j}+P_{c} \alpha^{j}+\boldsymbol{x}_{c} \chi^{j}+\varepsilon_{c}^{j}
$$

$T_{c}^{j}$ is energy use for country $c$ for energy type $j$. We assess solar photovoltaic, solar thermal, and wind, considering both primary energy and electricity generation. Considering electricity in addition to primary energy is important because the International Energy Agency (IEA) data tend to understate the role of solar and wind as primary energy sources due to the high inefficiency of some combustible energy generation (Sauar, 2017). This issue does not affect measures of the electricity generated (in megawatt hours) by each energy source.

$S_{c}$ is a variable of policy support. For the international sample, we use a binary variable with value of 1 for countries with a carbon price in 2010 at a national or sub-national level and 0 otherwise. 35 countries had a carbon price in 2010, including 32 countries with a nationallevel carbon price, and three countries (United States, Canada, and Japan) with a sub-national carbon price (Kossoy et al., 2015). Binary variables are useful given the difficulty in accurately measuring cardinal policy variables for a large sample of countries. Carbon prices, for example, are difficult to compare across countries due to differences in sectoral and geographical coverage, and as a result of the various other types of exemptions that are commonly applied (Kossoy et al. 2015). Prior authors have also noted that the intensity of renewable energy policy instruments is often challenging to measure (Zhao et al., 2013 for example). Daily changes in exchange rates and prices for emissions trading systems introduce further complications. The carbon pricing instrument variable in this paper includes both emissions trading systems and taxes.

For the EU sample, $S_{c}$ is a comprehensive measure of aggregate policy support from an Ecofys (2014) report prepared for the European Commission. We use wind policy support in the wind regressions and solar policy support in the solar regressions. We use the intensity of energy policy support, in thousand euro (2012) per megawatt hour. The Ecofys (2014) report aims to provide consistent and complete data for all $28 \mathrm{EU}$ countries, monetizing a broad range of policies including research and development, investment support such as investment 
grants, and support to production such as feed-in-tariffs. ${ }^{1}$ For instance, the euro values for renewable energy quotas with tradable certificates are either taken from national reports, or calculated as the price of certificates multiplied by the quantity of certificates. The use of a comprehensive policy support variable, in euro values, helps to avoid the high multicollinearity that would exist if one were to use many separate variables for each individual policy, as countries typically use more than one policy tool to reduce emissions. $P_{c}$ in equation (1) is for preferences or perceptions. For the EU sample, we use the percentage of respondents who think that their national government should focus on development of solar (or wind) energy, from a one-off European Commission (2006) survey. For our international sample, we use the percentage of respondents who see climate change as a serious personal threat from a Gallup (2009) survey covering 128 countries. The percentage of citizens in each country that view climate change as a personal threat is related to renewable energy preference, as renewable energy is a primary means to address climate change.

$\boldsymbol{x}_{c}$ is a vector of other potential determinants including log GDP per capita, log global horizontal irradiance, log wind energy potential, log energy use per capita, government effectiveness, a political globalization variable, binary variables for specific policies of feedin tariffs and renewable energy credits, ${ }^{2}$ private credit from deposit money banks, insurance assets, and domestic private debt. The error term is $\varepsilon_{c}^{j}$, with $E\left(\varepsilon_{c}^{j}\right)=0$. Our cross-sectional regressions use ordinary least squares estimates with standard errors that are robust to heteroscedasticity.

\subsection{Cross-sectional versus temporal variation}

Analysis of cross-sectional variation is appropriate for our study for a number of reasons. The primary reason is that we are interested in identifying the underlying factors affecting renewables uptake on a country-by-country basis, so as to understand why some countries have been more successful than others. This focus is naturally suited to a cross-country rather than time-series analysis. A second reason is that time-series variation in some of the variables is either not available (as is the case for the solar preference variable) or reflects

\footnotetext{
${ }^{1}$ One of the production support measures that the Ecofys (2014) report monetizes is the free allocation of emissions allowances in the EU emissions trading system, but this is not included in the solar and wind policy support measures that we use.

${ }^{2}$ It is difficult to quantify these specific policies in a manner that is consistent across a broad range of countries. Binary variables for policies are often used in the literature (Brunnschweiler, 2010; Pfeiffer and Mulder, 2013, for example).
} 
short-term variation that may not immediately affect our dependent variables given the lags involved in adopting renewable energy. Our cross-sectional estimates avoid the precise specification of time-series dynamics, allowing for a more parsimonious modelling approach.

We also present panel estimations. We use the between estimator, which Stern (2010) notes can be seen as a cross-sectional regression on the time-series mean of the data for each country. The between estimator allows analysis using multiple years of data, while avoiding the issue of non-stationary time-series data. Like cross-sectional estimates, the between estimator is typically interpreted as providing long-run effects.

\subsection{Lagged explanatory variables}

Our main cross-sectional estimates use 5-year lags in most cases. The preference data are from more than five years prior to the energy use data due to the timing of the preference surveys: energy preferences for EU citizens are from 2005, and climate change perceptions for the international group of countries are from 2007-2008. These lags allow time for preferences and perceptions to be translated into policies and potential future outcomes. We also experiment with alternative lag lengths: the panel regression results in section 4 use a 3year lag for the explanatory variables. Additional results with alternative lag lengths are available on request.

Use of lags allows for effects of the explanatory variables to be captured comprehensively: both short-term and medium-term effects will be included if the lag length is sufficiently long. This is important for some variables in particular that work with a delayed impact, such as the research and development component of the aggregate policy support variable. Also, policies and preferences for solar energy in the past may promote installation of solar energy infrastructure in the past, but once installed, it would generally produce solar electricity for a considerable period of time (longer than our lags).

Using lagged variables for the cross-sectional regression could be a problem if the explanatory variables change considerably over time. For instance, preferences for energy types are likely to vary over time, although it does not seem to us that there have been large shocks to preferences for solar or wind energy in the way that there have been for nuclear power, for example. It is possible that the Fukushima nuclear disaster led to greater preference for solar and wind energy, although there are many other alternative energy types also. The fossil fuel share of energy in Japan, for example, increased from 81 percent to over 94 percent following the Fukushima nuclear disaster. The lag length will not be a major issue 
for variables that are highly persistent. There are strong positive correlations between different years of the aggregate policy support variables of up to 0.96. For an example related to perceptions, the correlation between Gallup (2009; 2011) polls in 2007/8 and 2010 on climate change perception was $0.9 .{ }^{3}$ Preferences for renewable energy types have also been found to be at a consistently high level in industrialized countries (Renewable Energies Agency, 2016).

\subsection{Challenges for estimation}

Reverse causation from energy use to policy support is one potential source of endogeneity. For instance, some production or consumption subsidies are proportional to renewable energy use. To reduce endogeneity concerns, we use policy variables in euros per unit of energy rather than in aggregate terms. Reverse causation to financial variables is unlikely to be a major issue, as components of financial sectors are large and mature in many countries relative to the size of investment flows into solar and wind energy capacity.

Omitted variable bias is another potential source of endogeneity. While the EU policy support variable that we use is not measured perfectly, it is intended to be comprehensive. To further address the issue of potentially missing policy variables, we control for government effectiveness, a comprehensive variable measuring the quality of policy formulation and implementation in general. For parsimony we have not controlled for fossil fuel reserves. The correlations between fossil fuel reserves and modern renewable energy use are low in Table A.2.

Finally, we note that it is challenging to precisely evaluate policy impacts using observed data (Athey and Imbens, 2017). This is because it is not possible to conduct a controlled experiment for policy impacts at the macroeconomic level. For instance, carbon prices are not exogenous treatments; they could be more likely in countries that also employ other policies favoring renewable energy, or in countries where renewable energy lobbyists are more successful.

\footnotetext{
${ }^{3}$ There is evidence of some changes in climate change perceptions at sub-national levels. Konisky et al. (2016) find a temporary positive relationship between extreme weather activity and concern about climate change using data for storm events across the United States.
} 


\subsection{Data and sources}

We use energy variables from the International Energy Agency (IEA, 2017), including energy use per capita and its five-year change, energy shares, and corresponding electricity levels and changes. Table 1 shows the average values for solar and wind energy shares and per capita levels. While the average shares are relatively low, some countries have much higher shares. Denmark had a wind share of total primary energy supply of 8 percent in 2015 .

Table 1. Average energy use by type, 2015.

\begin{tabular}{lcrrr}
\hline & Share (EU) & Share (global) & $\begin{array}{r}\text { Primary energy } \\
\text { use per capita } \\
\text { (EU) }\end{array}$ & $\begin{array}{r}\text { Primary energy } \\
\text { use per capita } \\
\text { (global) }\end{array}$ \\
\hline Wind & 0.015 & 0.005 & 0.045 & 0.012 \\
Solar PV & 0.004 & 0.001 & 0.011 & 0.003 \\
Solar Thermal & 0.003 & 0.001 & 0.008 & 0.003 \\
\hline
\end{tabular}

Notes: These mean values cover 28 countries for the EU sample and 139 countries for the global sample. Share is percentage of total primary energy supply divided by 100. Primary energy use per capita is in tonnes of oil equivalent. Source: IEA (2017).

Data sources for the explanatory variables include the World Bank (2017) for gross domestic product, total energy use per capita, and population. Data for global horizontal irradiance are from Breyer and Gerlach (2010; 2013), while data on wind energy potential are from Lu et al. (2009). We use government effectiveness data from the Worldwide Governance Indicators (2015), and political globalization data from the KOF Index of Globalization (Dreher, 2006). We also use binary variables for countries with feed-in tariff and renewable energy certificate policies, based on the Global Status Report from REN21 (2011). The financial data are from the Global Financial Development Database (GFDD, 2017). We look at different institutional and market components of financial systems. For financial institutions, a key variable with wide data availability is private credit by deposit money banks divided by GDP. We also consider private debt and insurance company assets.

The correlations between each potential determinant and solar and wind energy use are shown in the Appendix (Table A.2). The variables with the highest correlations with solar and wind energy are those in the policy, preference, and financial capital categories. The five highest positive correlations with wind energy include three financial variables and two policy variables. For solar PV, the five highest positive correlations include two variables on perceptions and preferences and three variables on policy. In the case of solar thermal, all three of the key categories of policies, preferences, and financial capital feature in the top five. Table A.2 also includes a number of other variables with lower correlations with solar 
and wind energy use, such as fossil fuel reserves and trade openness. Our regressions focus on the variables with the higher correlations in Table A.2: those variables measuring policies, preferences, and financial capital.

The potential importance of the explanatory variables for solar and wind energy use is evident in Figures 1-4. Both solar and wind energy are greater on average in 2015 for countries that were classified as high-income (Figure 1), that had a carbon price in 2010 (Figure 2), had larger financial systems relative to their economy as proxied by private credit as a percentage of GDP (Figure 3), and that had higher percentages of citizens who were concerned about climate change (Figure 4). For wind energy, climate change perception appears to have less impact in Figure 4 than the variables in the other figures. For solar energy, private credit appears to have less impact in Figure 3 than the variables in the other figures. The figures do not imply causation given that the key explanatory variables are each correlated with other factors. Our regressions (section 4) will seek to identify conditional effects.

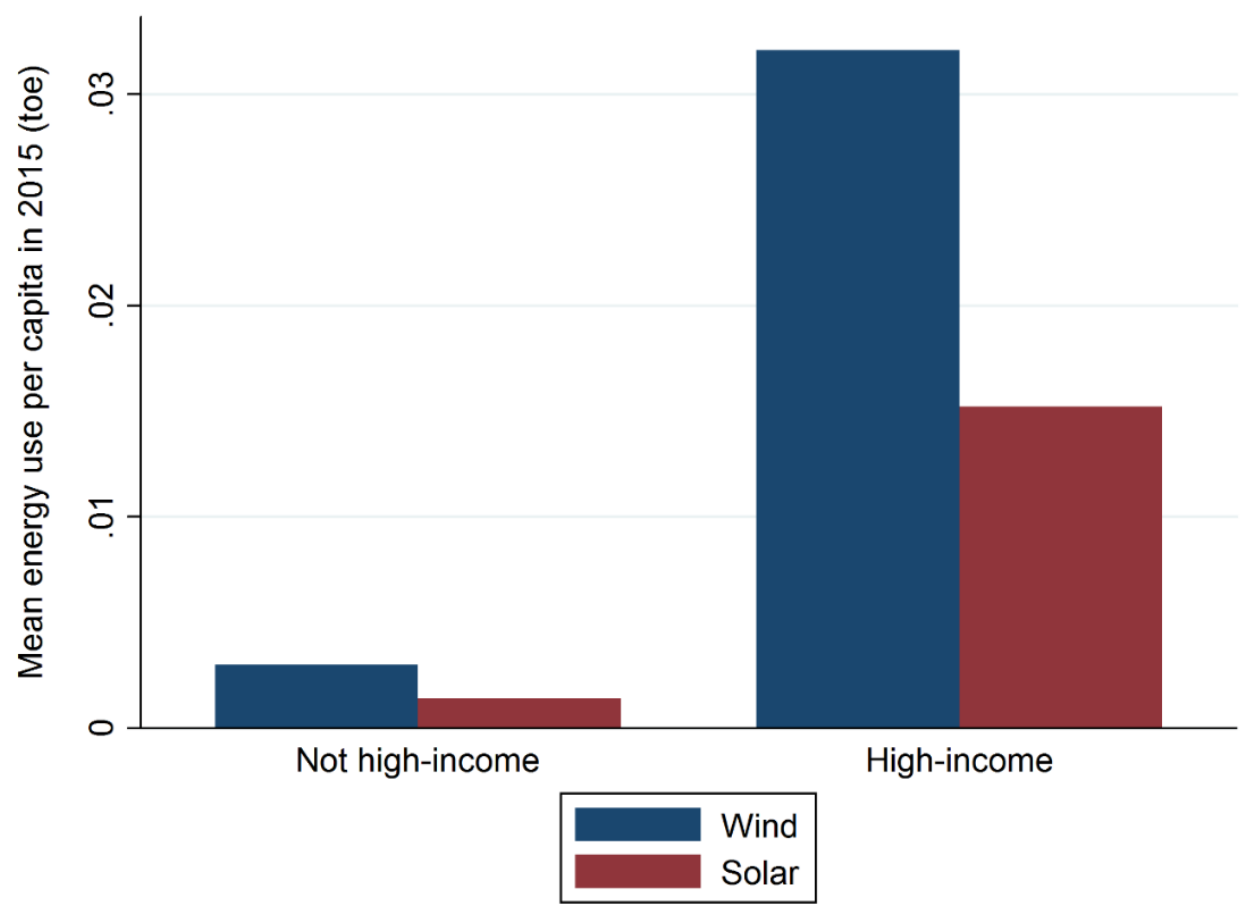

Fig. 1. Energy use (solar and wind) per capita in tonnes of oil equivalent, split into two income groups: High-income and not-high income based on 2010 World Bank income groups. 138 countries are included with energy data for 2015, based on data availability. Sources: IEA (2017), World Bank (2017). Notes: toe is tonnes of oil equivalent. 


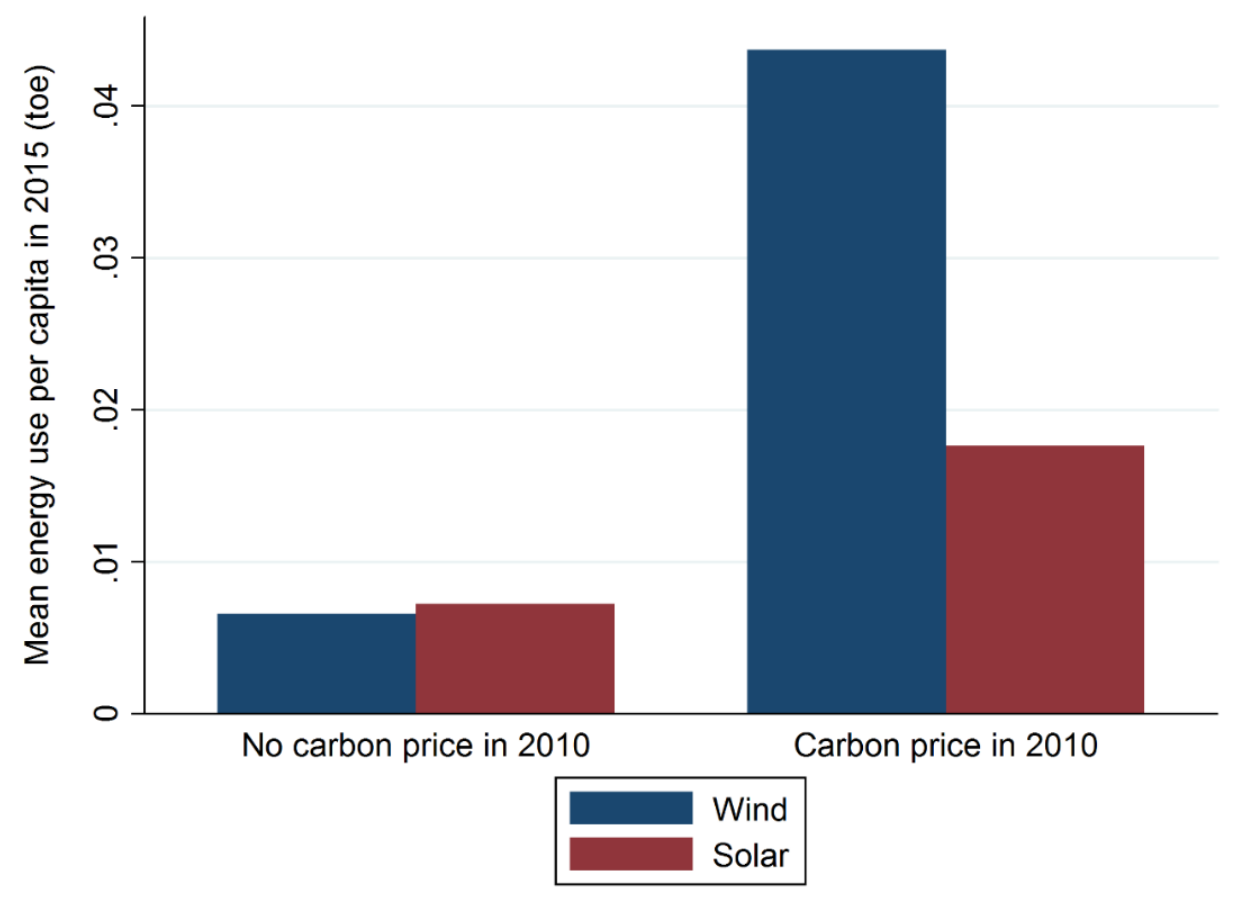

Fig. 2. Energy use (solar and wind) per capita in tonnes of oil equivalent, split by carbon price status in 2010. 44 high-income countries are included with energy data for 2015, based on data availability. 30 high-income countries had a carbon price in 2010. Sources: IEA (2017), Kossoy et al. (2015).

Notes: toe is tonnes of oil equivalent.

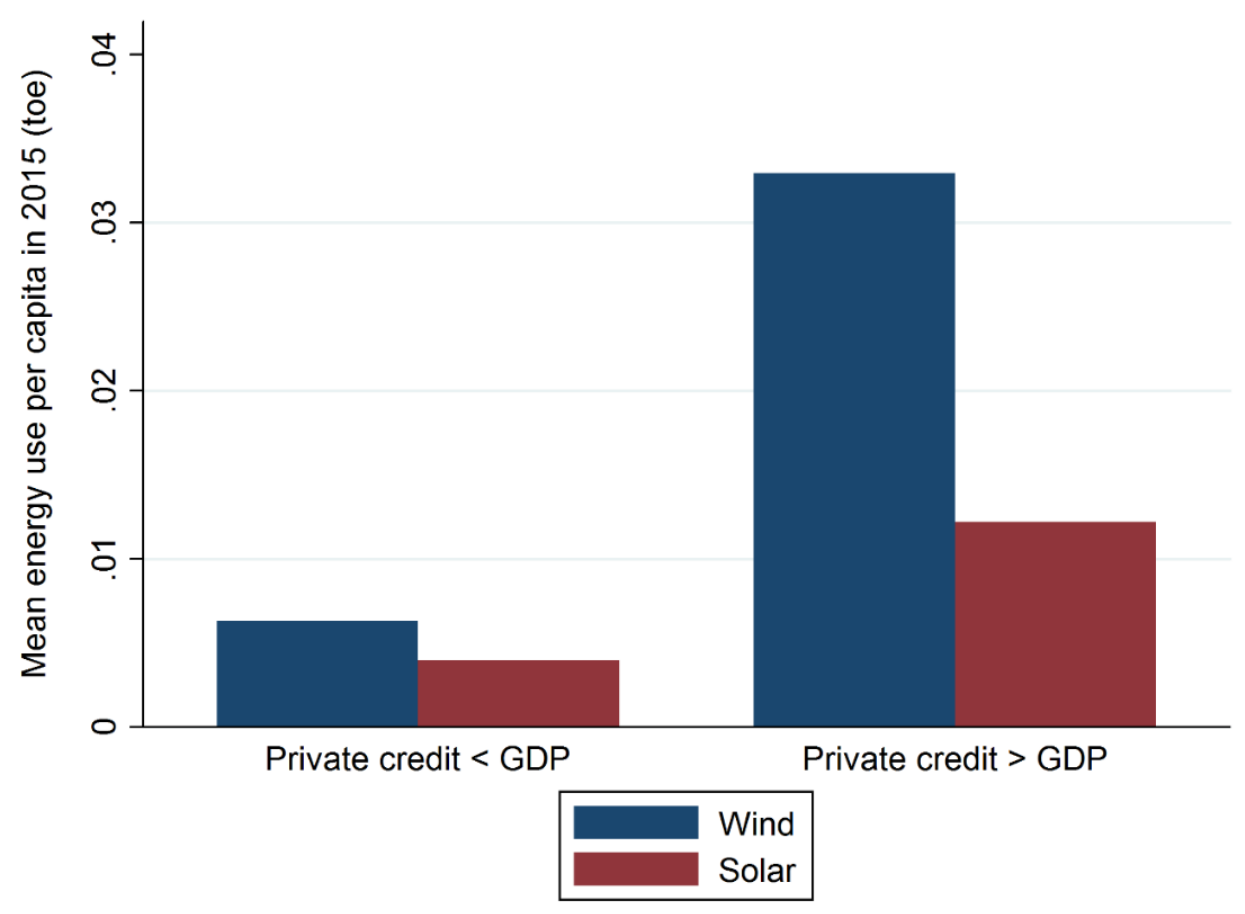

Fig. 3. Energy use (solar and wind) per capita in tonnes of oil equivalent, split into two groups based on size of private credit as a percentage of GDP. The two groups are private credit less than GDP and private credit greater than GDP. 138 countries are included with energy data for 2015, based on data availability. Sources: IEA (2017), GFDD (2017). Notes: toe is tonnes of oil equivalent. 


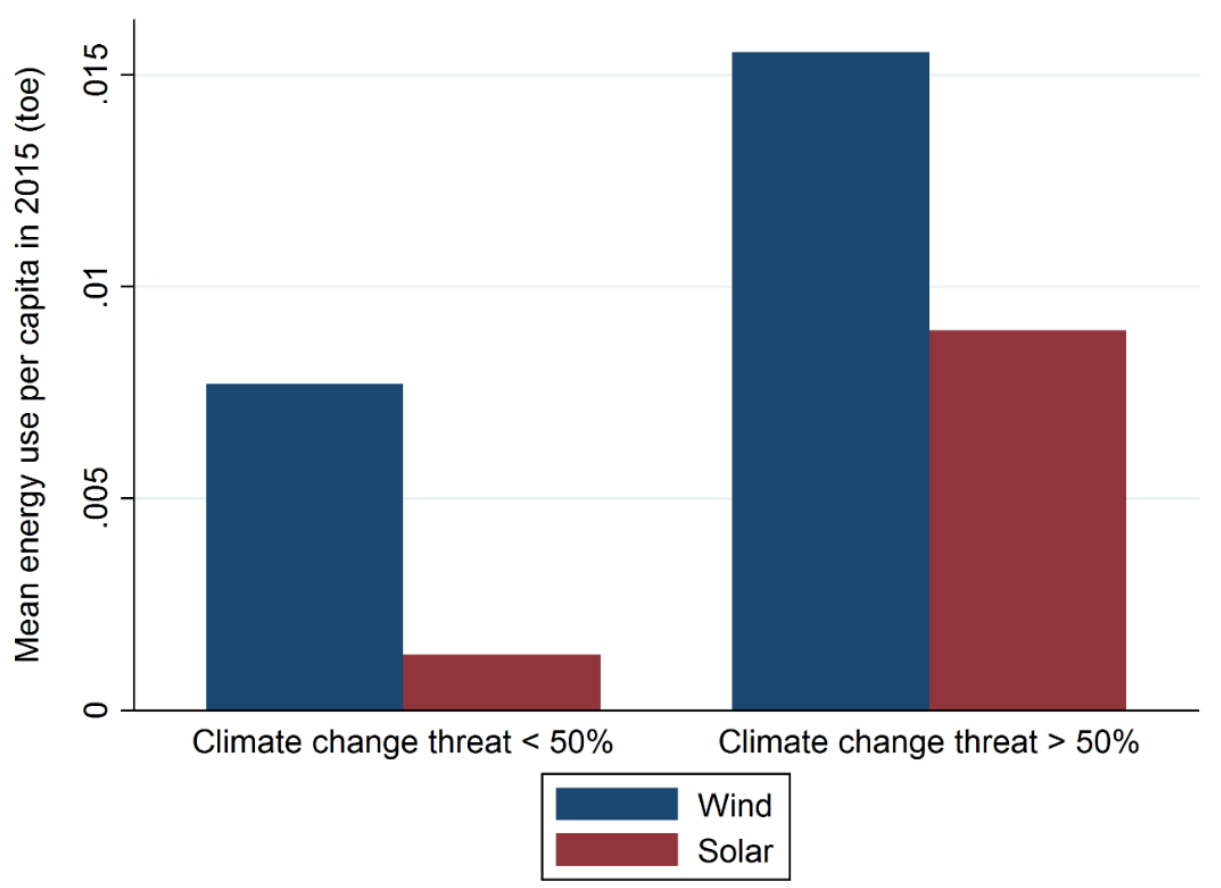

Fig. 4. Energy use (solar and wind) per capita in tonnes of oil equivalent, split by climate change perceptions of citizens. The first group is countries where less than $50 \%$ of citizens viewed climate change as a serious personal threat, and the second group is greater than 50\%. 138 countries are included with energy data for 2015, based on data availability. Sources: IEA (2017), Gallup (2009).

Notes: toe is tonnes of oil equivalent.

\section{Results and discussion}

\subsection{Solar energy results and discussion}

Table 2 shows solar energy results for the international sample of countries. There are positive and significant coefficients for the carbon price variable in each column of Table 2. For example, the coefficient in column 5 for the solar share of electricity is 0.024 , significant at the one percent level. This implies that countries with a carbon price in 2010 had a solar share of electricity in 2015 that was on average 2.4 percentage points higher than countries without a carbon price in 2010, all else equal. Results are similar if only countries with a carbon price at a national level are assigned a value of 1 , with countries with only subnational carbon prices (United States, Canada, and Japan in 2010) assigned a value of 0. It is possible that the carbon pricing coefficient might be driven by omitted variables rather than carbon pricing itself, but the carbon pricing variable remains significant when controlling for a binary feed-in tariff variable in the final three columns. A positive association between the binary carbon pricing variable and solar energy use is observable despite the low levels of current carbon prices relative to estimates of the social cost of carbon (United Nations, 2017). It is possible that even a low carbon price could encourage renewable energy use when there 
is only a small cost gap between energy types, or when having a carbon price increases expectations of the future carbon price level.

Table 2 also suggests that climate change perceptions make a considerable contribution to solar energy adoption. For a one percentage point increase in the proportion of citizens perceiving climate change to be a serious personal threat in 2007-2008, there are increases in 2015 of 0.004 percentage points in the solar share of energy in the column 2 and 0.02 percentage points in the solar share of electricity generation in column 5 . These are small effects for solar energy use in absolute magnitude, but a one percentage point increase in citizen climate change perception is also small relative to the within-sample range of 15 to 85 percent.

The coefficients of many of the explanatory variables in Table 2 are not significant, with some notable exceptions. The log of global horizontal irradiance has positive and significant coefficients in four columns, suggesting that countries with more abundant solar resources have adopted more solar energy. This effect occurs primarily for solar photovoltaic energy rather than solar thermal energy (results available on request). There are also positive and significant coefficients for the global political participation variable in four columns. Greater solar energy use, in place of alternative fossil fuel sources, is one way that countries can meet global environmental obligations. 
Table 2. Results for solar energy, 2015, global sample of countries.

\begin{tabular}{|c|c|c|c|c|c|c|}
\hline & (1) & (2) & (3) & (4) & (5) & (6) \\
\hline & $\begin{array}{r}\text { Solar energy per } \\
\text { capita }\end{array}$ & $\begin{array}{r}\text { Solar share of } \\
\text { energy }\end{array}$ & $\begin{array}{r}\text { Solar energy p.c. } \\
\text { change }\end{array}$ & $\begin{array}{r}\text { Solar electricity } \\
\mathrm{pc}\end{array}$ & $\begin{array}{r}\text { Solar share of } \\
\text { electricity }\end{array}$ & $\begin{array}{l}\text { Solar elect. } \\
\text { p.c. change }\end{array}$ \\
\hline Perceived threat of climate change (lag) & $\begin{array}{r}0.020 * * * \\
(0.006)\end{array}$ & $\begin{array}{r}0.004 * * \\
(0.002)\end{array}$ & $\begin{array}{l}0.008 * \\
(0.004)\end{array}$ & $\begin{array}{r}0.108 * * \\
(0.047)\end{array}$ & $\begin{array}{r}0.017 * * \\
(0.008)\end{array}$ & $\begin{array}{r}0.097 * * \\
(0.042)\end{array}$ \\
\hline Carbon price (lag) & $\begin{array}{r}0.011 * * * \\
(0.003)\end{array}$ & $\begin{array}{r}0.005 * * \\
(0.002)\end{array}$ & $\begin{array}{r}0.019 * * \\
(0.008)\end{array}$ & $\begin{array}{r}0.127 * * * \\
(0.039)\end{array}$ & $\begin{array}{r}0.024 * * * \\
(0.007)\end{array}$ & $\begin{array}{r}0.101 * * * \\
(0.035)\end{array}$ \\
\hline Private credit divided by GDP (lag) & & $\begin{array}{r}0.005^{* *} \\
(0.002)\end{array}$ & $\begin{array}{r}0.006 \\
(0.004)\end{array}$ & $\begin{array}{r}0.003 \\
(0.036)\end{array}$ & $\begin{array}{r}0.004 \\
(0.006)\end{array}$ & $\begin{array}{r}-0.003 \\
(0.028)\end{array}$ \\
\hline Insurance assets divided by GDP (lag) & & $\begin{array}{r}-0.006 * * \\
(0.003)\end{array}$ & $\begin{array}{r}-0.005 \\
(0.007)\end{array}$ & $\begin{array}{r}0.014 \\
(0.070)\end{array}$ & $\begin{array}{r}-0.002 \\
(0.011)\end{array}$ & $\begin{array}{r}0.023 \\
(0.059)\end{array}$ \\
\hline Log GDP per capita (lag) & & $\begin{array}{r}0.000 \\
(0.001)\end{array}$ & $\begin{array}{r}0.001 \\
(0.002)\end{array}$ & $\begin{array}{l}-0.009 \\
(0.017)\end{array}$ & $\begin{array}{r}0.002 \\
(0.003)\end{array}$ & $\begin{array}{r}-0.007 \\
(0.014)\end{array}$ \\
\hline Log global horizontal irradiance & & $\begin{array}{r}0.011 * * * \\
(0.003)\end{array}$ & $\begin{array}{r}0.010 \\
(0.008)\end{array}$ & $\begin{array}{r}0.188 * * * \\
(0.063)\end{array}$ & $\begin{array}{r}0.030 * * * \\
(0.011)\end{array}$ & $\begin{array}{r}0.158 * * * \\
(0.056)\end{array}$ \\
\hline Log wind energy potential & & $\begin{array}{r}-0.000 \\
(0.000)\end{array}$ & $\begin{array}{r}0.002 \\
(0.001)\end{array}$ & $\begin{array}{r}0.002 \\
(0.007)\end{array}$ & $\begin{array}{r}-0.001 \\
(0.001)\end{array}$ & $\begin{array}{r}0.001 \\
(0.006)\end{array}$ \\
\hline Log energy use per capita (lag) & & $\begin{array}{l}-0.000 \\
(0.001)\end{array}$ & $\begin{array}{l}-0.001 \\
(0.002)\end{array}$ & $\begin{array}{r}0.021 \\
(0.018)\end{array}$ & $\begin{array}{r}0.002 \\
(0.003)\end{array}$ & $\begin{array}{r}0.018 \\
(0.016)\end{array}$ \\
\hline Globalization: political partic. (lag) & & $\begin{array}{r}0.008 * * * \\
(0.003)\end{array}$ & $\begin{array}{r}0.005 \\
(0.007)\end{array}$ & $\begin{array}{r}0.125 * * \\
(0.061)\end{array}$ & $\begin{array}{r}0.026 * * \\
(0.012)\end{array}$ & $\begin{array}{l}0.103 * \\
(0.052)\end{array}$ \\
\hline Government effectiveness (lag) & & $\begin{array}{r}0.000 \\
(0.001)\end{array}$ & $\begin{array}{r}-0.005 \\
(0.005)\end{array}$ & $\begin{array}{r}0.008 \\
(0.023)\end{array}$ & $\begin{array}{r}-0.004 \\
(0.004)\end{array}$ & $\begin{array}{r}0.006 \\
(0.021)\end{array}$ \\
\hline Feed-in tariff (lag) & & & & $\begin{array}{r}0.015 \\
(0.014)\end{array}$ & $\begin{array}{r}0.002 \\
(0.002)\end{array}$ & $\begin{array}{r}0.013 \\
(0.011)\end{array}$ \\
\hline Observations & 108 & 89 & 89 & 74 & 74 & 74 \\
\hline $\mathrm{R}^{2}$ & 0.299 & 0.491 & 0.264 & 0.500 & 0.508 & 0.512 \\
\hline
\end{tabular}

Notes: $* * *, * * *$ show statistical significance at 1,5 and 10 per cent level respectively. Energy change dependent variables are five-year changes to 2015 . Private credit, insurance company assets, log GDP per capita, globalization: political participation, government effectiveness, and energy use are lagged by 5 years. Perceived threat of climate change is based on a survey from 2007-2008. Carbon price is a binary variable with value of 1 for countries that had a carbon price in 2010 , and feed-in tariff is a binary variable with value of 1 for countries that had adopted feed-in tariffs prior to 2011. Robust standard errors are in brackets below the coefficients. Coefficients for constants are not shown. 
Table 3 presents panel regressions using the between estimator with solar energy data for European Union countries for 2011-2015. The estimates suggest that aggregate policy support is positively associated with solar energy use, all else equal, with positive and significant coefficients in three of the columns. An additional euro per megawatt hour of aggregate policy support is associated with 0.004 additional percentage points of solar PV electricity share in column 1 , and 0.002 percentage points of solar thermal energy share in column 5. For context, the average support in the estimation sample is approximately 200 euro per megawatt hour. Our results showing the importance of aggregate policy support for solar energy are comparable to other studies that identify the importance of specific policies such as feed-in tariffs for renewable energy (Carley et al., 2016, for example).

Preference for solar energy is positively associated with solar energy adoption for the EU sample of countries in Table 3. The solar preference variable has positive coefficients in each column, although the only significant estimates are at the ten percent level in both column 4 and column 5 (the regressions for the solar thermal share of energy).

The explanatory variables in Table 3 help to explain large fractions of the variation in solar energy use, with the R-squared in the final two columns exceeding 0.7 , although most variables are not significant. This non-significance could be partly due to the small sample of EU countries. Log GDP per capita has positive and significant coefficients for the solar PV regressions but not for solar thermal. There are positive and significant coefficients for the private credit variable in the solar thermal regressions, but not for solar PV. These differences may relate to different financing structures for solar PV and solar thermal, with different mixes of small-scale and utility-scale installations. 
Table 3. Results for solar energy (PV and thermal separately), 2011-2015, between estimator, European Union countries.

\begin{tabular}{|c|c|c|c|c|c|c|}
\hline & (1) & (2) & (3) & (4) & (5) & $(6)$ \\
\hline & $\begin{array}{r}\text { Solar PV share of } \\
\text { electricity }\end{array}$ & $\begin{array}{r}\text { Solar PV share } \\
\text { of electricity }\end{array}$ & $\begin{array}{r}\text { Solar PV } \\
\text { electricity per } \\
\text { capita }\end{array}$ & $\begin{array}{r}\text { Solar thermal } \\
\text { share of } \\
\text { energy }\end{array}$ & $\begin{array}{l}\text { Solar thermal } \\
\text { share of energy }\end{array}$ & $\begin{array}{r}\text { Solar thermal } \\
\text { energy per } \\
\text { capita }\end{array}$ \\
\hline Preference for solar energy & $\begin{array}{r}0.012 \\
(0.026)\end{array}$ & $\begin{array}{r}0.009 \\
(0.031)\end{array}$ & $\begin{array}{r}0.137 \\
(0.196)\end{array}$ & $\begin{array}{l}0.017 * \\
(0.009)\end{array}$ & $\begin{array}{l}0.016 * \\
(0.009)\end{array}$ & $\begin{array}{r}0.026 \\
(0.019)\end{array}$ \\
\hline Aggregate solar policy support per MWh (lag) & $\begin{array}{r}0.035 * * \\
(0.015)\end{array}$ & $\begin{array}{l}-0.001 \\
(0.021)\end{array}$ & $\begin{array}{r}0.011 \\
(0.137)\end{array}$ & $\begin{array}{r}0.008 \\
(0.005)\end{array}$ & $\begin{array}{r}0.019 * * * \\
(0.006)\end{array}$ & $\begin{array}{r}0.039 * * * \\
(0.013)\end{array}$ \\
\hline Private credit divided by GDP (lag) & & $\begin{array}{r}-0.002 \\
(0.010)\end{array}$ & $\begin{array}{r}-0.024 \\
(0.067)\end{array}$ & & $\begin{array}{r}0.009 * * * \\
(0.003)\end{array}$ & $\begin{array}{r}0.015^{* * *} \\
(0.006)\end{array}$ \\
\hline Log GDP per capita (lag) & & $\begin{array}{r}0.058 * * \\
(0.021)\end{array}$ & $\begin{array}{r}0.284 * * \\
(0.134)\end{array}$ & & $\begin{array}{r}-0.008 \\
(0.006)\end{array}$ & $\begin{array}{l}-0.015 \\
(0.013)\end{array}$ \\
\hline Log global horizontal irradiance & & $\begin{array}{r}0.042 \\
(0.034)\end{array}$ & $\begin{array}{r}0.203 \\
(0.216)\end{array}$ & & $\begin{array}{r}-0.012 \\
(0.010)\end{array}$ & $\begin{array}{l}-0.016 \\
(0.021)\end{array}$ \\
\hline Log wind energy potential & & $\begin{array}{r}0.003 \\
(0.003)\end{array}$ & $\begin{array}{r}0.025 \\
(0.021)\end{array}$ & & $\begin{array}{r}-0.002 \\
(0.001)\end{array}$ & $\begin{array}{l}-0.003 \\
(0.002)\end{array}$ \\
\hline Log energy use per capita (lag) & & $\begin{array}{r}0.029 \\
(0.020)\end{array}$ & $\begin{array}{r}0.199 \\
(0.129)\end{array}$ & & $\begin{array}{r}-0.003 \\
(0.006)\end{array}$ & $\begin{array}{r}-0.006 \\
(0.012)\end{array}$ \\
\hline Government effectiveness (lag) & & $\begin{array}{r}-0.037 * * \\
(0.015)\end{array}$ & $\begin{array}{r}-0.195^{*} \\
(0.094)\end{array}$ & & $\begin{array}{r}-0.000 \\
(0.004)\end{array}$ & $\begin{array}{r}0.001 \\
(0.009)\end{array}$ \\
\hline Globalization: political partic. (lag) & & $\begin{array}{r}-0.033 \\
(0.034)\end{array}$ & $\begin{array}{l}-0.165 \\
(0.215)\end{array}$ & & $\begin{array}{r}-0.001 \\
(0.010)\end{array}$ & $\begin{array}{r}0.007 \\
(0.021)\end{array}$ \\
\hline $\begin{array}{l}\text { Observations } \\
\mathrm{R}^{2} \text { (between) }\end{array}$ & $\begin{array}{r}138 \\
0.286\end{array}$ & $\begin{array}{r}131 \\
0.617\end{array}$ & $\begin{array}{r}131 \\
0.558\end{array}$ & $\begin{array}{r}138 \\
0.351\end{array}$ & $\begin{array}{r}131 \\
0.783\end{array}$ & $\begin{array}{r}131 \\
0.754\end{array}$ \\
\hline
\end{tabular}

Notes: ***, **, * show statistical significance at 1, 5 and 10 per cent level respectively. Policy support, government effectiveness, global political participation, energy use,

GDP per capita, and private credit are lagged by 3 years. Preference for solar energy is based on a one-time survey from 2005 , and solar and wind resources are long-term averages. Coefficients for constants are not shown. Standard errors are in brackets below the coefficients. Two outlier values for Poland are excluded (solar subsidies per megawatt hour in 2011 and 2012 are reported as over 30,000 euro, but none of the other EU countries had values above 1,600). Inclusion of these two outliers causes the positive and significant coefficients for solar policy support to become insignificant. 


\subsection{Wind energy results and discussion}

Table 4 shows a positive contribution of policy for wind energy for the international sample of countries, with the carbon pricing variable being significant in two columns. There is significance in four of the columns when only national-level schemes are counted in the carbon pricing variable. The carbon price variable is still significant in column 5 when controlling for adoption of tradable renewable energy credits. The tradable renewable energy credits variable has a positive correlation with wind energy use per capita, but the correlation between the carbon price variable and wind energy use per capita is considerably higher in Table A.2.

In Table 4, financial capital is a key contributor, with positive and significant coefficients for private credit in three columns. To assess another financial component, we include insurance company assets. The coefficients for insurance company asset size in Table 4 are also positive and significant in three columns. This suggests that multiple sources of financial capital are important, other than just bank assets, as insurance companies hold diversified asset portfolios including bonds and equity.

Table 4 also has some other notable coefficients. Log GDP per capita has positive and significant coefficients in each column, and log of total energy use per capita has negative and significant coefficients. The positive coefficients for log GDP per capita are consistent with the finding of Burke (2010) that wind energy use has primarily been in higher-income countries. The coefficients for log wind energy potential are positive but not significant, but we find that countries with more solar resources tend to use less wind energy, with significance in two columns. This is consistent with the positive relationship between the log of global horizontal irradiance and solar energy in Table 2 given that solar and wind are substitutes. Climate change perception does not have a significant effect on wind energy use in any of the six columns of Table 4. Perhaps this is because the channel from climate change perception to greater renewable energy use is more indirect for wind energy when compared to solar energy; concerned citizens can directly install solar PV panels on individual rooftops, whereas the majority of wind energy is generated from large turbines. 
Table 4. Results for wind energy, 2015, global sample of countries.

\begin{tabular}{|c|c|c|c|c|c|c|}
\hline & (1) & (2) & (3) & (4) & (5) & (6) \\
\hline & $\begin{array}{r}\text { Wind energy per } \\
\text { capita }\end{array}$ & $\begin{array}{r}\text { Wind share of } \\
\text { energy }\end{array}$ & $\begin{array}{r}\text { Wind energy } \\
\text { p.c. change }\end{array}$ & $\begin{array}{r}\text { Wind electricity } \\
\text { per capita }\end{array}$ & $\begin{array}{r}\text { Wind share of } \\
\text { electricity }\end{array}$ & $\begin{array}{l}\text { Wind elect. per } \\
\text { capita change }\end{array}$ \\
\hline Perceived threat of climate change (lag) & $\begin{array}{r}0.008 \\
(0.016)\end{array}$ & $\begin{array}{r}0.002 \\
(0.008)\end{array}$ & $\begin{array}{r}-0.008 \\
(0.009)\end{array}$ & $\begin{array}{r}-0.155 \\
(0.249)\end{array}$ & $\begin{array}{r}-0.016 \\
(0.052)\end{array}$ & $\begin{array}{l}-0.096 \\
(0.119)\end{array}$ \\
\hline Carbon price (lag) & $\begin{array}{r}0.045 * * * \\
(0.010)\end{array}$ & $\begin{array}{r}0.006 \\
(0.004)\end{array}$ & $\begin{array}{r}0.001 \\
(0.007)\end{array}$ & $\begin{array}{r}0.202 \\
(0.131)\end{array}$ & $\begin{array}{r}0.052 * * \\
(0.024)\end{array}$ & $\begin{array}{r}0.014 \\
(0.081)\end{array}$ \\
\hline Private credit divided by GDP (lag) & & $\begin{array}{r}0.014 * * \\
(0.006)\end{array}$ & $\begin{array}{r}0.005 \\
(0.006)\end{array}$ & $\begin{array}{c}0.324^{*} \\
(0.188)\end{array}$ & $\begin{array}{c}0.076^{*} \\
(0.039)\end{array}$ & $\begin{array}{r}0.038 \\
(0.078)\end{array}$ \\
\hline Insurance assets divided by GDP (lag) & & $\begin{array}{r}0.006 \\
(0.007)\end{array}$ & $\begin{array}{c}0.025^{*} \\
(0.013)\end{array}$ & $\begin{array}{c}0.505^{*} \\
(0.260)\end{array}$ & $\begin{array}{r}0.051 \\
(0.042)\end{array}$ & $\begin{array}{r}0.358 * * \\
(0.168)\end{array}$ \\
\hline Log GDP per capita (lag) & & $\begin{array}{r}0.006 * * * \\
(0.002)\end{array}$ & $\begin{array}{c}0.005^{*} \\
(0.003)\end{array}$ & $\begin{array}{c}0.120^{*} \\
(0.070)\end{array}$ & $\begin{array}{r}0.045 * * * \\
(0.015)\end{array}$ & $\begin{array}{l}0.071 * \\
(0.038)\end{array}$ \\
\hline Log global horizontal irradiance & & $\begin{array}{r}-0.004 \\
(0.005)\end{array}$ & $\begin{array}{r}-0.031 * * \\
(0.013)\end{array}$ & $\begin{array}{r}-0.309 \\
(0.228)\end{array}$ & $\begin{array}{r}-0.034 \\
(0.033)\end{array}$ & $\begin{array}{r}-0.417 * * \\
(0.168)\end{array}$ \\
\hline Log wind energy potential & & $\begin{array}{r}0.000 \\
(0.000)\end{array}$ & $\begin{array}{r}0.000 \\
(0.001)\end{array}$ & $\begin{array}{r}0.019 \\
(0.021)\end{array}$ & $\begin{array}{r}0.003 \\
(0.003)\end{array}$ & $\begin{array}{r}0.009 \\
(0.011)\end{array}$ \\
\hline Log energy use per capita (lag) & & $\begin{array}{r}-0.007 * * * \\
(0.003)\end{array}$ & $\begin{array}{r}-0.007 * * \\
(0.003)\end{array}$ & $\begin{array}{r}-0.158^{*} \\
(0.089)\end{array}$ & $\begin{array}{r}-0.050 * * \\
(0.019)\end{array}$ & $\begin{array}{r}-0.096 * * \\
(0.046)\end{array}$ \\
\hline Globalization: political partic. (lag) & & $\begin{array}{r}-0.002 \\
(0.007)\end{array}$ & $\begin{array}{r}-0.003 \\
(0.008)\end{array}$ & $\begin{array}{r}-0.038 \\
(0.258)\end{array}$ & $\begin{array}{r}-0.066 \\
(0.068)\end{array}$ & $\begin{array}{r}-0.063 \\
(0.132)\end{array}$ \\
\hline Government effectiveness (lag) & & $\begin{array}{r}-0.002 \\
(0.002)\end{array}$ & $\begin{array}{r}0.003 \\
(0.003)\end{array}$ & $\begin{array}{r}0.027 \\
(0.066)\end{array}$ & $\begin{array}{r}-0.015 \\
(0.014)\end{array}$ & $\begin{array}{r}0.047 \\
(0.050)\end{array}$ \\
\hline Renewable energy credits (lag) & & & & $\begin{array}{r}-0.135^{*} \\
(0.080)\end{array}$ & $\begin{array}{r}-0.016 \\
(0.015)\end{array}$ & $\begin{array}{l}-0.066 \\
(0.057)\end{array}$ \\
\hline Observations & 108 & 89 & 89 & 74 & 74 & 74 \\
\hline $\mathrm{R}^{2}$ & 0.394 & 0.507 & 0.593 & 0.618 & 0.465 & 0.592 \\
\hline
\end{tabular}

Notes: ***, **, * show statistical significance at 1, 5 and 10 per cent level respectively. Energy change dependent variables are five-year changes to 2015 . Private credit, insurance company assets, GDP per capita, globalization: political participation, government effectiveness, and energy use are lagged by 5 years. Perceived threat of climate change is based on a survey from 2007-2008. Carbon price and renewable energy credits are binary variables with value of 1 for countries that had these policies in 2010 and 2011 respectively. Robust standard errors are in brackets below the coefficients. Coefficients for constants are not shown. Excluding Denmark, which has large financial markets and wind energy consumption per capita, produces similar results. 
The significant coefficients explaining wind energy and electricity in Table 4 are nearly all different to the significant coefficients explaining solar energy and electricity in Table 2. For wind, there are positive and significant coefficients for private credit, insurance assets, and $\log$ GDP per capita. There are negative and significant coefficients for the log of global horizontal irradiance and for total energy use per capita. The positive and significant coefficients for solar are for climate change perception, the log of global horizontal irradiance, and political participation in globalization. Positive and significant coefficients for the carbon pricing variable are seen in both the wind and solar regressions.

Table 5 presents panel estimates using EU data for wind energy from 2011-2015. Table 5 suggests that financial capital appears to have been important for adoption of wind energy. The coefficients for domestic private debt are positive and significant at the one percent level in four columns. This variable also has the highest correlation with wind energy use per capita in Table A.2 in the Appendix. Column 3 has a positive and significant coefficient for another financial variable, private credit, when omitting the domestic private debt variable to allow for a larger sample. The positive contribution of financial capital to wind energy suggests that this capital-intensive energy type has recently benefitted from larger supplies of private capital. Our results are consistent with intuition that (financial) markets play a larger role for relatively more mature technologies such as wind energy in 2015, while aggregate government support is more influential for technologies at an earlier stage of development, such as solar energy in 2015.

Policies and perceptions are not key determinants of wind energy use for the EU sample of countries in Table 5. The lack of a significant effect of aggregate policy support on wind energy use may be because levels of support for wind have been quite low. Aggregate policy support per megawatt hour for wind energy was less than a quarter of the corresponding amount for solar energy from 2008-2012. 
Table 5. Results for wind energy, 2011-2015, between estimator, European Union countries.

\begin{tabular}{|c|c|c|c|c|c|c|}
\hline & (1) & (2) & (3) & (4) & (5) & (6) \\
\hline & $\begin{array}{r}\text { Wind energy } \\
\text { per capita }\end{array}$ & $\begin{array}{r}\text { Wind share of } \\
\text { energy }\end{array}$ & $\begin{array}{r}\text { Wind share of } \\
\text { energy }\end{array}$ & $\begin{array}{r}\text { Wind } \\
\text { electricity pc }\end{array}$ & $\begin{array}{r}\text { Wind share of } \\
\text { electricity }\end{array}$ & $\begin{array}{r}\text { Wind share of } \\
\text { electricity }\end{array}$ \\
\hline \multirow[t]{2}{*}{ Preference for wind energy } & -0.032 & -0.012 & 0.029 & -0.376 & -0.053 & 0.154 \\
\hline & $(0.069)$ & $(0.023)$ & $(0.024)$ & $(0.806)$ & $(0.107)$ & $(0.153)$ \\
\hline \multirow[t]{2}{*}{ Aggregate wind policy support per MWh (lag) } & -0.260 & -0.092 & -0.067 & -3.023 & -0.283 & -0.307 \\
\hline & $(0.189)$ & $(0.061)$ & $(0.057)$ & $(2.193)$ & $(0.290)$ & $(0.364)$ \\
\hline \multirow[t]{2}{*}{ Private credit divided by GDP (lag) } & 0.024 & 0.012 & $0.016^{*}$ & 0.279 & 0.059 & 0.070 \\
\hline & $(0.022)$ & $(0.007)$ & $(0.008)$ & $(0.259)$ & $(0.034)$ & $(0.052)$ \\
\hline \multirow[t]{2}{*}{ Log GDP per capita (lag) } & -0.031 & -0.023 & 0.005 & -0.356 & -0.138 & 0.052 \\
\hline & $(0.056)$ & $(0.018)$ & $(0.017)$ & $(0.650)$ & $(0.086)$ & $(0.107)$ \\
\hline \multirow[t]{2}{*}{ Log global horizontal irradiance } & -0.018 & 0.001 & -0.014 & -0.211 & -0.015 & -0.123 \\
\hline & $(0.039)$ & $(0.013)$ & $(0.016)$ & $(0.451)$ & $(0.060)$ & $(0.103)$ \\
\hline \multirow[t]{2}{*}{ Log wind energy potential } & 0.001 & 0.000 & 0.000 & 0.017 & 0.001 & -0.003 \\
\hline & $(0.006)$ & $(0.002)$ & $(0.003)$ & $(0.065)$ & $(0.009)$ & $(0.016)$ \\
\hline \multirow[t]{2}{*}{ Log energy use per capita (lag) } & -0.012 & -0.000 & -0.019 & -0.141 & -0.022 & -0.158 \\
\hline & $(0.052)$ & $(0.017)$ & $(0.015)$ & $(0.606)$ & $(0.080)$ & $(0.097)$ \\
\hline \multirow[t]{2}{*}{ Government effectiveness (lag) } & 0.008 & 0.001 & -0.002 & 0.089 & 0.007 & 0.001 \\
\hline & $(0.027)$ & $(0.009)$ & $(0.011)$ & $(0.313)$ & $(0.041)$ & $(0.071)$ \\
\hline \multirow[t]{2}{*}{ Globalization: political partic. (lag) } & 0.118 & 0.046 & $0.056^{*}$ & 1.368 & 0.194 & 0.275 \\
\hline & $(0.094)$ & $(0.031)$ & $(0.026)$ & $(1.091)$ & $(0.145)$ & $(0.169)$ \\
\hline \multirow[t]{2}{*}{ Domestic private debt divided by GDP (lag) } & $0.081 * * *$ & $0.031 * * *$ & & $0.945 * * *$ & $0.191 * * *$ & \\
\hline & $(0.022)$ & $(0.007)$ & & $(0.260)$ & $(0.034)$ & \\
\hline Observations & 90 & 90 & 133 & 90 & 90 & 133 \\
\hline $\mathrm{R}^{2}$ (between) & 0.868 & 0.890 & 0.633 & 0.868 & 0.921 & 0.538 \\
\hline
\end{tabular}

Notes: $* * * * *, *$ show statistical significance at 1,5 and 10 per cent level respectively. All explanatory variables are lagged by three years, except for preference for wind energy, global horizontal irradiance, and wind resources. Preference for wind energy is based on a one-time survey from 2005. Solar and wind resources are long-term averages. Standard errors are in brackets below the coefficients. Coefficients for constants are not shown. 


\section{Brief case studies}

We now present brief case studies of countries' experiences in adopting solar and wind energy technologies.

Denmark followed an ambitious and multi-dimensional policy approach to the adoption of renewables. Policies have included taxes on energy and pollution, investment subsidies and longterm finance guarantees for wind energy capital costs, as well as encouragement of local cooperative ownership of wind turbines (Sovacool, 2013). Denmark was an early adopter of wind energy, with policy support commencing in 1976, and considerable growth in wind power capacity up to 2002 (Gavard, 2016). Denmark now has the highest wind energy use per capita in the world (see Table A.3). The results in the previous section suggest that carbon pricing in Denmark has likely contributed to greater wind energy use.

Germany provides another example of multi-dimensional policy approaches, with early and ambitious renewable energy goals, including detailed regulatory provisions that differentiate between renewable technology types (Strunz et al., 2016), as well as considerable support for solar energy adoption. Solar energy policy support has fallen as the technology has improved, although solar subsidies per megawatt hour were still above the EU average in 2010. Germany had the highest level of solar PV energy use per capita in the world in 2015.

There are a number of similarities in the renewable energy use, preferences, and policies for Baltic and Nordic countries. ${ }^{4}$ Solar energy adoption has been very low up to 2015 , but wind energy adoption has been much higher. A higher proportion of citizens thought that their national governments should focus on wind energy compared to solar energy in 2005 in Baltic and Nordic countries, in contrast to the situation in every other EU country except Ireland (European Commission, 2006). Solar policy support per megawatt hour in Baltic and Nordic countries has also generally been lower than wind policy support, again in contrast to many other EU countries.

\section{Conclusion and policy implications}

This paper finds evidence of differing determinants of solar and wind energy adoption. Carbon pricing appears to have been important for early adoption of solar energy. In addition, there is a positive association between aggregate policy support and solar energy use. We do not find evidence of a positive association between aggregate policy support and wind energy adoption for the period 2011-2015, but we do find evidence of a positive impact of carbon pricing. There is

\footnotetext{
${ }^{4}$ Baltic countries include Estonia, Latvia, and Lithuania. Nordic countries include Sweden, Norway, Denmark, Finland, and Iceland.
} 
evidence that perceiving climate change as a threat has been associated with greater solar but not wind energy use. It also appears that the size of domestic financial capital supplies has contributed to greater wind energy use but the effects on solar energy have been less clear. There appears to be a positive association between private credit and solar thermal energy use, but not solar PV energy use. Our results provide historical context regarding the early development of solar and wind energy. They are of ongoing policy relevance as more countries increase their adoption of solar and wind energy.

Our results show that aggregate policy support could be important for technologies at an early stage of development, such as solar energy for the period 2011-2015. In the early years of solar energy adoption, considerable support per unit of energy production was required, as solar energy was still expensive. The lack of a positive association between aggregate policy support for wind energy and wind energy use for the period 2011-2015 suggests that policy support may not be as crucial a determinant for adoption of more mature energy types such as wind power. Wind power had received lower levels of support per megawatt hour from 2008-2012 and is already cost competitive in some cases. There could have been a positive effect of wind policy support for earlier periods when wind energy was less mature. For instance, Gavard (2016) finds that policy support, including feed-in tariffs, increased wind energy deployment in Denmark from 2000-2010.

The positive relationship between carbon pricing and solar and wind energy adoption suggests that policy composition is important in addition to aggregate policy support. Governments could further consider the merits of carbon pricing, not only as a low-cost approach to reducing carbon dioxide emissions, but also given our new evidence of effects on renewables uptake, even with current low levels of carbon prices. Countries could consider commencing with a low carbon price, an approach that may face less political opposition than attempting to introduce a high carbon price. Early adoption of carbon pricing could help to avoid the lock-in of less efficient subsidy policies.

The contribution of preferences and perceptions to explaining solar energy adoption rates implies that an emphasis on education might be important. Educators and policymakers could give greater attention to explaining the fundamental issues and principles related to climate change and renewable energy policy. In particular, they could encourage long-term, balanced, and holistic perspectives. In-depth knowledge of climate change may not be necessary for all individuals, but a general understanding could be useful. This greater focus on education could provide a more solid foundation, encouraging support for evidence-based policies, and reducing uncertainty over adverse future policy changes. Targeting potentially receptive audiences for climate change education, 
rather than those strongly opposed, may be an effective strategy; Wendling et al. (2013) suggest that greater public support for immediate climate change action might involve motivating people with moderate climate change perceptions to increase their conviction.

The positive association between solar preference and solar energy use motivates further research and consideration of policy options to leverage this relationship. It is possible that the relationship between solar preference and solar use could be stronger if constraints and barriers are lessened. This could lead to greater solar energy use. Policymakers could particularly consider targeting policy support in cases where solar preference is strong but where barriers prevent greater use.

We also found that financial capital has been important for wind energy adoption. The aggregate size of financial institutions such as banks is an important contributor to wind energy use in both the EU and global samples. Financial market composition has also been important; outstanding domestic private debt, for example, appears to have supported wind energy use. Financial policies may have a role in complementing direct carbon and energy policies. Any policy that favors debt over equity could have indirect impacts on wind energy adoption, given that our results suggest that debt has been important for wind energy. The size and composition of private financial institutions and markets could also be increasingly important for the solar energy industry as solar energy continues to mature. 


\section{References}

Aguirre, M., Ibikunle, G., 2014. Determinants of renewable energy growth: A global sample analysis. Energy Policy 69, 374-384.

Aldy, J.E., Stavins, R.E., 2012. The promise and problems of pricing carbon: Theory and experience. Journal of Environment and Development 21(2), 152-180.

Athey, S., Imbens, G.W., 2017. The state of applied econometrics: Causality and policy evaluation. J. Econ. Perspect. 31 (2), 3-32.

Baldwin, E., Carley, S., Brass, J.N., MacLean, L.M., 2016. Global renewable electricity policy: A comparative policy analysis of countries by income status. J. Comparative Policy Analysis, 1-22.

Barradale, M.J., 2010. Impact of public policy uncertainty on renewable energy investment: Wind power and the production tax credit. Energy Policy 38, 7698-7709.

Basher, S.A., Masini, A., Aflaki, S., 2015. Time series properties of the renewable energy diffusion process: Implications for energy policy design and assessment. Renew. and Sustainable Energy Reviews 52, 1680-1692.

Best, R., 2017. Switching towards coal or renewable energy? The effects of financial capital on energy transitions. Energy Econ. 63, 75-83.

Best, R., Burke, P.J., 2017. The importance of government effectiveness for transitions toward greater electrification in developing countries. Energies 10 (9), 1247.

Blakers, A., Lu, B., Stocks, M., 2017. 100\% renewable electricity in Australia. Energy 133, 471482.

Breyer, C., Gerlach, A., 2010. Population density and area weighted solar Irradiation: global overview on solar resource conditions for fixed tilted, 1-axis and 2-axis PV systems. $5^{\text {th }}$ World Conference on Photovoltaic Energy Conversion, Valencia, Spain.

Breyer, C., Gerlach A., 2013. Global overview on grid-parity', Progress in Photovoltaics: Research and Applications 21, 121-136.

Brunnschweiler, C., 2010. Finance for renewable energy: An empirical analysis of developing and transition economies. Environ. Dev. Econ. 15, 241-274.

Burke, P.J., 2010. Income, resources, and electricity mix. Energy Econ. 32, 616-626.

Burke, P.J., 2012. Climbing the electricity ladder generates carbon Kuznets curve downturns. Australian Journal of Agricultural and Resource Economics 56, 260-279.

Burke, P.J., 2013. The national-level energy ladder and its carbon implications. Environment and Development Economics 18 (4), 484-503.

Carley, S., 2009. State renewable energy electricity policies: An empirical evaluation of effectiveness. Energy Policy 37, 3071-3081.

Carley, S., Baldwin, E., MacLean, L.M., Brass, J.N., 2016. Global expansion of renewable energy generation: An analysis of policy instruments. Environ. Resource Econ. 1-44.

Corsatea, T.D., Giaccaria, S., Arantegui, R.L., 2014. The role of sources of finance on the development of wind technology. Renew. Energy 66, 140-149. 
DDPP (Deep Decarbonisation Pathways Project), 2015. Pathways to deep decarbonisation 2015 report - executive summary. SDSN (Sustainable Development Solutions Network - IDDRI (Institute for Sustainable Development and International Relations).

Della Croce, R., Kaminker, C., Stewart, F., 2011. The role of pension funds in financing green growth initiatives. OECD Publishing, Paris.

DiaCore, 2016. The impact of risks in renewable energy investments and the role of smart policies (Final report). Co-funded by the Intelligent Energy Europe Programme of the European Union, Contract number: IEE/12/833/SI2.645735.

Dreher, A., 2006. Does globalization affect growth? Evidence from a new index of globalization. Appl. Econ. 38, 1091-1110.

Ecofys, 2014. Subsidies and costs of EU energy. Final report for the European Commission. 11 November 2014. Project number: DESNL14583. Reviewer Dr. Kornelis Blok.

Ecofys, 2017. Mapping the cost of capital for wind and solar energy in south eastern European member states. 10 January 2017. Project number: EPONL17190.

Eleftheriadis, I.M., Anagnostopoulou, E.G., 2015. Identifying barriers in the diffusion of renewable energy sources. Energy Policy 80, 153-164.

European Commission, 2006. Attitudes towards energy. Special Eurobarometer 247 / Wave 64.2, publication January 2006.

Friebe, C.A., von Flotow, P., Täube, F.A., 2014. Exploring technology diffusion in emerging markets - the role of public policy for wind energy. Energy Policy 70, 217-226.

Gallup, 2009. Top-emitting countries differ on climate change threat. By Anita Pugliese and Julie Ray, http://www.gallup.com/poll/124595/Top-Emitting-Countries-Differ-Climate-ChangeThreat.aspx, December 7, 2009. Accessed 7 March, 2017.

Gallup, 2011. Fewer Americans, Europeans view global warming as a threat. By Anita Pugliese and Julie Ray, http://news.gallup.com/poll/147203/fewer-americans-europeans-view-global-warmingthreat.aspx, April 20, 2011. Accessed 24 October, 2017.

Gavard, C., 2016. Carbon price and wind power support in Denmark. Energy Policy 92, 455-467.

GFDD (Global Financial Development Database), 2017. The World Bank http://data.worldbank.org/data-catalog/global-financial-development. Accessed 3 February, 2017.

Hepburn, C., 2017. Make carbon pricing a priority. Nature Climate Change 7, June 2017, 389-390.

Hirth, L., Steckel, J.C., 2016. The role of capital costs in decarbonizing the electricity sector. Environ. Res. Lett. 11114101.

IEA (International Energy Agency), 2014. World Energy Investment Outlook: Special Report. OECD/IEA, Paris, France.

IEA (International Energy Agency), 2015. Projected costs of generating electricity 2015 Edition. OECD/IEA, Paris, France.

IEA (International Energy Agency), 2016. Next generation wind and solar power: From cost to value. OECD/IEA, Paris, France.

IEA (International Energy Agency), 2017. IEA World Energy Statistics and Balances. IEA, Paris. Accessed 3 February, 2017). 
Jaffe, A.B., Newell, R.G., Stavins, R.N., 2005. A tale of two market failures: Technology and environmental policy. Ecological Economics 54, 164-174.

Johnstone, N., Hascic, I., Popp, D., 2010. Renewable energy policies and technology innovation: Evidence based on patent counts. Environ. Resour. Econ. 45, 133-155.

Kaminker, C., Stewart, F., 2012. The role of institutional investors in financing clean energy. OECD Working Papers on Finance, Insurance and Private Pensions, No.23, OECD Publishing.

Konisky, D.M., Hughes, L., Kaylor, C.H., 2016. Extreme weather events and climate change concern. Climatic Change 134, 533-547.

Kossoy, A., Peszko, G., Oppermann, K., Prytz, N., Klein, N., Blok, K., Lam, L., Wong, L., Borkent, B., 2015. State and Trends of Carbon Pricing 2015 (September). World Bank, Washington, DC.

Lin, B., Omoju, O.E., 2017. Focusing on the right targets: Economic factors driving non-hydro renewable energy transition. Renew. Energy 113, 52-63.

Lu, X., McElroy, M.B., Kiviluoma, J., 2009. Global potential for wind-generated electricity. Proceedings of the National Academy of Sciences 106 (27), 10933-10938.

Mankiw, N, G., 2009. Smart taxes: An open invitation to join the Pigou club. Eastern Economic Journal 35, 14-23.

Murakami, K., Ida, T., Tanaka, M., Friedman, L., 2015. Consumers' willingness to pay for renewable and nuclear energy: A comparative analysis between the US and Japan. Energy Econ. 50, $178-189$.

Ng, T.H., Tao J.Y., 2016. Bond financing for renewable energy in Asia. Energy Policy 95, 509517.

OECD/IEA and IRENA (Organisation for Economic Co-operation and Development / International Energy Agency and International Renewable Energy Agency), 2017. Perspectives for the energy transition: Investment needs for a low-carbon energy system. Executive summary.

Omri, A., Nguyen D.K., 2014. On the determinants of renewable energy consumption: International evidence. Energy 72, 554-560.

Ondraczek, J., Komendantova, N., Patt, A., 2015. WACC the dog: The effect of financing costs on the levelized cost of solar PV power. Renew. Energy 75, 888-898.

Pfeiffer, B., Mulder, P., 2013. Explaining the diffusion of renewable energy technology in developing countries. Energy Econ. 40, 285-296.

Polzin, F., Migendt, M., Täube, F.A., von Flotow, P., 2015. Public policy influence on renewable energy investments - A panel data study across OECD countries. Energy Policy 80, 98-111.

Popp, D., Hascic, I., Medhi, N., 2011. Technology and the diffusion of renewable energy. Energy Econ. 33, 648-662.

REN21 (Renewable Energy Policy Network for the $21^{\text {st }}$ century), 2011. Renewables 2011 Global Status Report. Paris: REN21 Secretariat.

Renewable Energies Agency, 2016. Renews Kompakt: Opinions on renewables - a look at polls in industrialised countries. Issue 29. Berlin, Germany. 
Sadorsky, P., 2009. Renewable energy consumption, CO2 emissions and oil prices in the G7 countries. Energy Econ. 31, 456-462.

Sauar, E., 2017. IEA counts fossil fuels threefold versus wind and solar. Energy and Climate. https://energiogklima.no/kommentar/iea-counts-fossil-fuels-threefold-versus-wind-and-solar/. Accessed 8 November, 2017.

Sener, C., Fthenakis, V., 2014. Energy policy and financing options to achieve solar energy grid penetration targets: Accounting for external costs. Renewable and Sustainable Energy Reviews 32, 854-868.

Smith, M.G., Urpelainen J., 2014. The effect of feed-in tariffs on renewable electricity generation: An instrumental variables approach. Environ. Resour. Econ. 57, 367-392.

Sovacool, B.K., 2013. Energy policymaking in Denmark: Implications for global energy security and sustainability. Energy Policy 61, 829-839.

Stern, D.I., 2010. Between estimates of the emissions-income elasticity. Ecological Economics 69, 2173-2182.

Strunz, S., Gawel, E., Lehmann, P., 2016. The political economy of renewable energy policies in Germany and the EU. Utilities Policy 42, 33-41.

US EIA (United States Energy Information Administration), 2017. International Energy Statistics. U.S. Energy Information Statistics.

http://www.eia.gov/beta/international/data/browser/\#/?vs=INTL.44-1-AFRC-

QBTU.A\&vo=0\&v=H\&start=1980\&end=2014.

Accessed 3 March, 2017.

United Nations, 2017. The emissions gap report 2017. A UN environment synthesis report. Job Number: DEW/2061/NA, November 2017.

Veugelers, R., 2012. Which policy instruments to induce clean innovating? Research Policy 41, 1770-1778.

Wendling, Z.A., Attari, S.Z., Carley, S.R., Krause, R.M., Warren, D.C., Rupp, J.A., Graham, J.D., 2013. On the importance of strengthening moderate beliefs in climate science to foster support for immediate action. Sustainability 5, 5153-5170.

World Bank, 2017, World Development Indicators, 1998-2015. World Bank. http://data.worldbank.org/ Accessed 3 March, 2017.

Worldwide Governance Indicators, 2015.

http://info.worldbank.org/governance/wgi/index.aspx\#home. Accessed 29 March, 2016.

Zhao, Y., Tang, K.K., Wang, L., 2013. Do renewable electricity policies promote renewable electricity generation? Evidence from panel data. Energy Policy 62, 887-897. 


\section{Appendix}

Table A.1: Description of variables that are in regressions or correlation table (A.2), grouped by type of variable.

\begin{tabular}{|c|c|c|}
\hline Variable & Source & Description \\
\hline Wind energy per capita & IEA & $\begin{array}{l}\text { Wind, total primary energy supply, tonnes of } \\
\text { oil equivalent per capita. }\end{array}$ \\
\hline Solar PV energy per capita & IEA & $\begin{array}{l}\text { Solar photovoltaics, total primary energy } \\
\text { supply, tonnes of oil equivalent per capita. }\end{array}$ \\
\hline Solar thermal energy per capita & IEA & $\begin{array}{l}\text { Solar thermal, total primary energy supply, } \\
\text { tonnes of oil equivalent per capita. }\end{array}$ \\
\hline Solar energy per capita & IEA & $\begin{array}{l}\text { Solar (PV plus thermal), total primary energy } \\
\text { supply, tonnes of oil equivalent per capita. }\end{array}$ \\
\hline Wind share of energy & IEA & $\begin{array}{l}\text { Wind share of total primary energy supply } \\
\text { (range } 0 \text { to } 1) \text {. }\end{array}$ \\
\hline Solar PV share of energy & IEA & $\begin{array}{l}\text { Solar PV share of total primary energy supply } \\
\text { (range } 0 \text { to } 1 \text { ). }\end{array}$ \\
\hline Solar thermal energy share & IEA & $\begin{array}{l}\text { Solar thermal share of total primary energy } \\
\text { supply (range } 0 \text { to } 1 \text { ). }\end{array}$ \\
\hline Solar share of energy & IEA & $\begin{array}{l}\text { Solar (PV plus thermal) share of total primary } \\
\text { energy supply (range } 0 \text { to } 1 \text { ). }\end{array}$ \\
\hline Wind electricity per capita & IEA & $\begin{array}{l}\text { Wind electricity output, megawatt hours per } \\
\text { capita. }\end{array}$ \\
\hline Solar PV electricity per capita & IEA & $\begin{array}{l}\text { Solar photovoltaic electricity output, } \\
\text { megawatt hours per capita. }\end{array}$ \\
\hline Solar thermal electricity per capita & IEA & $\begin{array}{l}\text { Solar thermal electricity output, megawatt } \\
\text { hours per capita. }\end{array}$ \\
\hline Solar electricity per capita & IEA & $\begin{array}{l}\text { Solar electricity output, megawatt hours per } \\
\text { capita. }\end{array}$ \\
\hline Preference for wind energy & $\mathrm{EC}$ & $\begin{array}{l}\text { Percentage of respondents who think that their } \\
\text { national government should focus on } \\
\text { development of wind power (QA65), divided } \\
\text { by } 100 \text {. Survey of } 24,924 \text { respondents from } \\
\text { EU countries (roughly } 1,000 \text { per country) } \\
\text { from } 2005 \text {. }\end{array}$ \\
\hline Preference for solar energy & $\mathrm{EC}$ & $\begin{array}{l}\text { Percentage of respondents who think that their } \\
\text { national government should focus on } \\
\text { development of solar power (QA65), divided } \\
\text { by } 100 \text {. Survey of } 24,924 \text { respondents from } \\
\text { EU countries (roughly } 1,000 \text { per country) } \\
\text { from } 2005 \text {. }\end{array}$ \\
\hline $\begin{array}{l}\text { Perceived threat of climate change } \\
\text { (international sample) }\end{array}$ & Gallup & $\begin{array}{l}\text { Percentage of respondents who think global } \\
\text { warming is a serious personal threat, divided } \\
\text { by } 100 \text {. Survey of } 206,193 \text { respondents from } \\
128 \text { countries in } 2007 \text { and } 2008 \text {. }\end{array}$ \\
\hline Globalization: political participation & KOF & $\begin{array}{l}\text { Political globalization index, values from } 0 \text { to } \\
100 \text {, divided by } 100 \text {, based on: number of } \\
\text { embassies, membership in international } \\
\text { organizations, participation in U.N. Security } \\
\text { Council Missions, international treaties. }\end{array}$ \\
\hline Renewable energy credits & REN21 & $\begin{array}{l}\text { Tradable renewable energy credits at national } \\
\text { or sub-national level, binary variable. }\end{array}$ \\
\hline
\end{tabular}




\begin{tabular}{|c|c|c|}
\hline Feed-in-tariffs & REN21 & $\begin{array}{l}\text { Feed-in tariff (including premium payment) at } \\
\text { national or sub-national level, binary variable. }\end{array}$ \\
\hline Carbon price & $\mathrm{WB} / \mathrm{Ec}$ & $\begin{array}{l}\text { National or subnational carbon pricing } \\
\text { instruments implemented, as of } 2010 \text {, binary } \\
\text { variable. } 35 \text { countries had carbon prices in } \\
2010 \text {. }\end{array}$ \\
\hline Wind RDD per capita & IEA & $\begin{array}{l}\text { Total wind energy research, development, } \\
\text { demonstration in million USD, } 2014 \text { prices } \\
\text { and PPP, per capita (population from WDI). }\end{array}$ \\
\hline Solar RDD per capita & IEA & $\begin{array}{l}\text { Total solar energy research, development, } \\
\text { demonstration in million USD, } 2014 \text { prices } \\
\text { and PPP, per capita (population from WDI). }\end{array}$ \\
\hline $\begin{array}{l}\text { Aggregate wind policy support per } \\
\text { megawatt hour }\end{array}$ & Eco & $\begin{array}{l}\text { Total policy support for wind electricity } \\
\text { (onshore plus offshore) including support for } \\
\text { research and development, investment, and } \\
\text { production in thousand Euro (2012) per } \\
\text { megawatt hour. }\end{array}$ \\
\hline $\begin{array}{l}\text { Aggregate solar policy support per } \\
\text { megawatt hour }\end{array}$ & Eco & $\begin{array}{l}\text { Total policy support for solar electricity } \\
\text { including support for research and } \\
\text { development, investment, and production in } \\
\text { thousand Euro (2012) per megawatt hour. }\end{array}$ \\
\hline Government effectiveness & WGI & $\begin{array}{l}\text { An index representing quality of public } \\
\text { services and quality of policy formulation and } \\
\text { implementation. The index values are } \\
\text { normally distributed with mean zero and } \\
\text { standard deviation of one. }\end{array}$ \\
\hline Weighted average cost of capital & Diac. & $\begin{array}{l}\text { Weighted average cost of capital (\%) for } \\
\text { onshore wind projects in countries across the } \\
\text { EU, based on interviews with experts (equity } \\
\text { providers, project developers, bankers) in } \\
2014 \text {. }\end{array}$ \\
\hline Private credit (\% of GDP) & GFDD & $\begin{array}{l}\text { Private credit by deposit money banks, } \% \text { of } \\
\text { GDP, divided by } 100 .\end{array}$ \\
\hline Domestic private debt (\% of GDP) & GFDD & $\begin{array}{l}\text { Outstanding domestic private debt securities, } \\
\% \text { of GDP, divided by } 100 .\end{array}$ \\
\hline Public debt ( $\%$ of GDP) & GFDD & $\begin{array}{l}\text { Outstanding public debt securities (domestic } \\
\text { and international), \% of GDP, divided by } 100 .\end{array}$ \\
\hline International priv. debt (\% of GDP) & GFDD & $\begin{array}{l}\text { Outstanding international private debt } \\
\text { securities, } \% \text { of GDP, divided by } 100 .\end{array}$ \\
\hline Equity capitalization ( $\%$ of GDP) & GFDD & $\begin{array}{l}\text { Stock market capitalization, \% of GDP, } \\
\text { divided by } 100 .\end{array}$ \\
\hline Foreign direct invest. ( $\%$ of GDP) & WDI & $\begin{array}{l}\text { Foreign direct investment, net inflows, } \% \text { of } \\
\text { GDP. }\end{array}$ \\
\hline Pension funds (\% of GDP) & GFDD & $\begin{array}{l}\text { Pension fund assets, } \% \text { of GDP, divided by } \\
100 .\end{array}$ \\
\hline Insurance assets (\% of GDP) & GFDD & $\begin{array}{l}\text { Insurance company assets, \% of GDP, divided } \\
\text { by } 100 .\end{array}$ \\
\hline Mutual funds ( $\%$ of GDP) & GFDD & $\begin{array}{l}\text { Mutual fund assets, \% of GDP, divided by } \\
100 .\end{array}$ \\
\hline Log GDP per capita & WDI & $\begin{array}{l}\text { Log gross domestic product per capita, } \\
\text { purchasing power parity, constant } 2011 \\
\text { international dollars. }\end{array}$ \\
\hline Trade openness & WDI & $\begin{array}{l}\text { Exports of goods and services plus imports, } \% \\
\text { of GDP. }\end{array}$ \\
\hline
\end{tabular}




\begin{tabular}{|c|c|c|}
\hline Log patents per capita & WDI & $\begin{array}{l}\text { Patent applications from residents and non- } \\
\text { residents, per capita, log. }\end{array}$ \\
\hline Log global horizontal irradiance & $\mathrm{B} \& \mathrm{G}$ & $\begin{array}{l}\text { Log mean global horizontal irradiance }(\mathrm{kWh} \\
\text { per meter squared per year), area weighted, } 0 \text { - } \\
\text { axis fixed tilted. }\end{array}$ \\
\hline Log wind energy potential & LU & $\begin{array}{l}\text { Log wind energy potential (with capacity } \\
\text { factors greater than } 20 \% \text { with siting limited as } \\
\text { discussed in Lu et al. (2009)). }\end{array}$ \\
\hline Coal reserves per capita & EIA & $\begin{array}{l}\text { Coal, recoverable reserves, 2014, million } \\
\text { short tons per capita. }\end{array}$ \\
\hline Oil reserves per capita & EIA & $\begin{array}{l}\text { Oil, recoverable reserves, 2014, billion barrels } \\
\text { per capita. }\end{array}$ \\
\hline Gas reserves per capita & EIA & $\begin{array}{l}\text { Natural gas, recoverable reserves, } 2014 \text {, } \\
\text { trillion cubic feet per capita. }\end{array}$ \\
\hline Log carbon dioxide emissions p.c. & IEA & $\begin{array}{l}\text { Carbon dioxide emissions, electricity and heat } \\
\text { production, thousand tonnes, per capita, log. }\end{array}$ \\
\hline Log energy use per capita & WDI & $\begin{array}{l}\text { Energy use, kilograms of oil equivalent per } \\
\text { capita, log. }\end{array}$ \\
\hline
\end{tabular}

Sources: B\&G: Breyer and Gerlach (2010), Diac: DiaCore (2016), EC: European Commission (2006), Eco: Ecofys (2014), EIA: U.S. Energy Information Administration (2017), GFDD: Global Financial Development Database (2017), IEA: International Energy Agency (2017), KOF: KOF Index of Globalization (Dreher 2006), LU: Lu et al. (2009), REN21: Renewable energy policy network for the $21^{\text {st }}$ century (From Table 2 of Global Status Report 2011: Renewable energy support policies), WB/Ec: Figure 2 from joint report by World Bank and Ecofys (Kossoy et al. 2015), WDI: World Bank World Development Indicators (2017), WGI: Worldwide Governance Indicators (2015). 
Table A.2: Correlations with wind, solar PV, and solar thermal energy per capita

\begin{tabular}{|c|c|c|c|c|}
\hline Variable & $\begin{array}{l}\text { Number of } \\
\text { countries/ } \\
\text { observations }\end{array}$ & $\begin{array}{l}\text { Correlation } \\
\text { with wind } \\
\text { energy per } \\
\text { capita }\end{array}$ & $\begin{array}{l}\text { Correlation } \\
\text { with solar } \\
\text { PV energy } \\
\text { per capita }\end{array}$ & $\begin{array}{l}\text { Correlation } \\
\text { with solar } \\
\text { thermal } \\
\text { energy p.c. }\end{array}$ \\
\hline Wind energy per capita & 138 & 1.00 & 0.35 & 0.25 \\
\hline Solar PV energy per capita & 138 & 0.35 & 1.00 & 0.39 \\
\hline Solar thermal energy per capita & 138 & 0.25 & 0.39 & 1.00 \\
\hline Preference for wind energy & 28 & 0.49 & -0.31 & -0.20 \\
\hline Preference for solar energy & 28 & -0.18 & 0.44 & 0.51 \\
\hline Perceived threat of climate change & 108 & 0.26 & 0.44 & 0.25 \\
\hline Globalization: political participation & 136 & 0.42 & 0.39 & 0.24 \\
\hline Renewable energy credits & 93 & 0.37 & 0.29 & -0.03 \\
\hline Feed-in-tariffs & 93 & 0.14 & 0.25 & 0.21 \\
\hline Carbon price & 139 & 0.59 & 0.59 & 0.29 \\
\hline Wind RDD & 25 & 0.40 & -0.22 & -0.11 \\
\hline Solar RDD & 25 & 0.02 & -0.09 & 0.05 \\
\hline Wind policy support per MWh & 28 & -0.10 & 0.21 & 0.32 \\
\hline Solar policy support per MWh & 28 & 0.01 & 0.49 & 0.33 \\
\hline Government effectiveness & 137 & 0.53 & 0.47 & 0.32 \\
\hline Weighted average cost of capital & 28 & -0.29 & -0.28 & 0.18 \\
\hline Private credit (\% of GDP) & 128 & 0.55 & 0.42 & 0.50 \\
\hline Domestic private debt (\% of GDP) & 49 & 0.72 & 0.15 & 0.16 \\
\hline Public debt (\% of GDP) & 48 & 0.05 & 0.38 & 0.06 \\
\hline International priv. debt ( $\%$ of GDP) & 74 & 0.39 & 0.21 & 0.09 \\
\hline Equity capitalization (\% of GDP) & 99 & -0.01 & 0.02 & 0.02 \\
\hline Foreign direct invest. (\% of GDP) & 135 & -0.04 & 0.20 & 0.21 \\
\hline Pension funds ( $\%$ of GDP) & 69 & 0.19 & 0.03 & 0.04 \\
\hline Insurance assets (\% of GDP) & 117 & 0.62 & 0.43 & 0.13 \\
\hline Mutual funds (\% of GDP) & 59 & 0.21 & -0.08 & -0.05 \\
\hline Log GDP per capita & 137 & 0.38 & 0.40 & 0.25 \\
\hline Trade openness & 136 & -0.01 & 0.07 & -0.02 \\
\hline Log patents per capita & 91 & 0.30 & 0.31 & 0.07 \\
\hline Log global horizontal irradiance & 130 & -0.49 & -0.21 & 0.09 \\
\hline Log wind energy potential & 137 & 0.21 & 0.08 & 0.01 \\
\hline Log carbon dioxide emissions p.c. & 135 & 0.23 & 0.31 & 0.20 \\
\hline Coal reserves per capita & 133 & 0.06 & 0.17 & 0.07 \\
\hline Oil reserves per capita & 129 & -0.08 & -0.10 & -0.06 \\
\hline Gas reserves per capita & 127 & -0.06 & -0.06 & -0.04 \\
\hline Log energy use per capita & 139 & 0.32 & 0.34 & 0.17 \\
\hline
\end{tabular}

Notes: Dependent variables (wind energy per capita, solar PV energy per capita, and solar thermal energy per capita) are for 2015. Independent variables are at a 5-year lag, consistent with the cross-sectional results, unless data are unavailable: please see Table A.1 for details. 
Table A.3: Key data: Global country sample

102 countries in the global sample with data available for energy, climate change preference, and private credit are listed in the following table (the first column of Table 2 and 4 include more countries because private credit is not a control in these columns). Carbon pricing status in 2010 is also shown. Energy variables are for 2015, perceived threat of climate change is from 2007/2008, and private credit is for 2010 .

\begin{tabular}{|c|c|c|c|c|c|c|}
\hline Country & $\begin{array}{c}\text { Wind } \\
\text { energy } \\
\text { per capita }\end{array}$ & $\begin{array}{c}\text { Solar PV } \\
\text { energy } \\
\text { per capita }\end{array}$ & $\begin{array}{c}\text { Solar } \\
\text { thermal } \\
\text { energy per } \\
\text { capita }\end{array}$ & $\begin{array}{c}\text { Perceived } \\
\text { threat of } \\
\text { climate } \\
\text { change }\end{array}$ & $\begin{array}{c}\text { Carbon } \\
\text { price }\end{array}$ & $\begin{array}{c}\text { Private } \\
\text { credit }(\% \\
\text { of } \\
\text { GDP/100) }\end{array}$ \\
\hline Algeria & 0.000 & 0.000 & 0.000 & 0.46 & 0 & 0.14 \\
\hline Angola & 0.000 & 0.000 & 0.000 & 0.38 & 0 & 0.18 \\
\hline Argentina & 0.001 & 0.000 & 0.000 & 0.71 & 0 & 0.10 \\
\hline Armenia & 0.000 & 0.000 & 0.000 & 0.65 & 0 & 0.25 \\
\hline Australia & 0.041 & 0.022 & 0.015 & 0.75 & 0 & 1.22 \\
\hline Austria & 0.048 & 0.009 & 0.021 & 0.54 & 1 & 0.97 \\
\hline Azerbaijan & 0.000 & 0.000 & 0.000 & 0.43 & 0 & 0.17 \\
\hline Bangladesh & 0.000 & 0.000 & 0.000 & 0.32 & 0 & 0.36 \\
\hline Belarus & 0.000 & 0.000 & 0.000 & 0.3 & 0 & 0.36 \\
\hline Belgium & 0.042 & 0.023 & 0.002 & 0.68 & 1 & 0.56 \\
\hline Benin & 0.000 & 0.000 & 0.000 & 0.15 & 0 & 0.22 \\
\hline Bolivia & 0.000 & 0.000 & 0.000 & 0.51 & 0 & 0.32 \\
\hline Botswana & 0.000 & 0.000 & 0.000 & 0.3 & 0 & 0.24 \\
\hline Brazil & 0.009 & 0.000 & 0.003 & 0.76 & 0 & 0.48 \\
\hline Cambodia & 0.000 & 0.000 & 0.000 & 0.51 & 0 & 0.25 \\
\hline Cameroon & 0.000 & 0.000 & 0.000 & 0.32 & 0 & 0.11 \\
\hline Chile & 0.010 & 0.006 & 0.002 & 0.69 & 0 & 0.63 \\
\hline China & 0.012 & 0.003 & 0.016 & 0.21 & 0 & 1.28 \\
\hline Colombia & 0.000 & 0.000 & 0.000 & 0.65 & 0 & 0.30 \\
\hline Congo, Rep. & 0.000 & 0.000 & 0.000 & 0.31 & 0 & 0.05 \\
\hline Costa Rica & 0.019 & 0.000 & 0.000 & 0.72 & 0 & 0.45 \\
\hline Czech Republic & 0.005 & 0.018 & 0.002 & 0.39 & 1 & 0.46 \\
\hline Denmark & 0.214 & 0.009 & 0.006 & 0.4 & 1 & 1.95 \\
\hline Dominican Rep. & 0.006 & 0.002 & 0.001 & 0.46 & 0 & 0.20 \\
\hline Ecuador & 0.001 & 0.000 & 0.000 & 0.69 & 0 & 0.22 \\
\hline Egypt & 0.001 & 0.000 & 0.000 & 0.21 & 0 & 0.32 \\
\hline El Salvador & 0.000 & 0.000 & 0.000 & 0.51 & 0 & 0.94 \\
\hline Estonia & 0.047 & 0.000 & 0.000 & 0.32 & 1 & 0.95 \\
\hline Finland & 0.037 & 0.000 & 0.000 & 0.39 & 1 & 0.86 \\
\hline France & 0.027 & 0.009 & 0.001 & 0.75 & 1 & 0.94 \\
\hline Georgia & 0.000 & 0.000 & 0.001 & 0.47 & 0 & 0.29 \\
\hline Germany & 0.084 & 0.041 & 0.008 & 0.6 & 1 & 0.91 \\
\hline Ghana & 0.000 & 0.000 & 0.000 & 0.19 & 0 & 0.14 \\
\hline Greece & 0.037 & 0.031 & 0.018 & 0.82 & 1 & 1.02 \\
\hline Guatemala & 0.001 & 0.001 & 0.000 & 0.51 & 0 & 0.23 \\
\hline Haiti & 0.000 & 0.000 & 0.000 & 0.35 & 0 & 0.13 \\
\hline Honduras & 0.007 & 0.000 & 0.000 & 0.57 & 0 & 0.47 \\
\hline Hong Kong, SAR & 0.000 & 0.000 & 0.000 & 0.54 & 0 & 1.64 \\
\hline Hungary & 0.006 & 0.001 & 0.001 & 0.75 & 1 & 0.60 \\
\hline Iceland & 0.003 & 0.000 & 0.000 & 0.33 & 1 & 1.70 \\
\hline India & 0.003 & 0.000 & 0.001 & 0.29 & 0 & 0.44 \\
\hline Indonesia & 0.000 & 0.000 & 0.000 & 0.33 & 0 & 0.22 \\
\hline
\end{tabular}




\begin{tabular}{|c|c|c|c|c|c|c|}
\hline Iran & 0.000 & 0.000 & 0.000 & 0.43 & 0 & 0.53 \\
\hline Iraq & 0.000 & 0.000 & 0.000 & 0.28 & 0 & 0.04 \\
\hline Ireland & 0.122 & 0.000 & 0.003 & 0.6 & 1 & 1.54 \\
\hline Israel & 0.000 & 0.011 & 0.043 & 0.62 & 0 & 0.85 \\
\hline Italy & 0.021 & 0.032 & 0.003 & 0.76 & 1 & 0.90 \\
\hline Japan & 0.003 & 0.024 & 0.003 & 0.8 & 1 & 1.05 \\
\hline Jordan & 0.001 & 0.000 & 0.021 & 0.51 & 0 & 0.68 \\
\hline Kazakhstan & 0.001 & 0.000 & 0.000 & 0.35 & 0 & 0.41 \\
\hline Kenya & 0.000 & 0.000 & 0.000 & 0.49 & 0 & 0.31 \\
\hline Korea, Rep. & 0.002 & 0.007 & 0.001 & 0.8 & 0 & 0.92 \\
\hline Kyrgyz Rep. & 0.000 & 0.000 & 0.000 & 0.39 & 0 & 0.12 \\
\hline Latvia & 0.006 & 0.000 & 0.000 & 0.37 & 1 & 0.95 \\
\hline Lebanon & 0.000 & 0.000 & 0.004 & 0.54 & 0 & 0.70 \\
\hline Lithuania & 0.024 & 0.002 & 0.000 & 0.47 & 1 & 0.58 \\
\hline Luxembourg & 0.015 & 0.016 & 0.003 & 0.75 & 1 & 0.97 \\
\hline Malaysia & 0.000 & 0.001 & 0.000 & 0.5 & 0 & 1.02 \\
\hline Malta & 0.000 & 0.019 & 0.010 & 0.64 & 1 & 1.17 \\
\hline Mexico & 0.006 & 0.000 & 0.002 & 0.63 & 0 & 0.18 \\
\hline Moldova & 0.000 & 0.000 & 0.000 & 0.73 & 0 & 0.32 \\
\hline Mongolia & 0.005 & 0.000 & 0.000 & 0.3 & 0 & 0.37 \\
\hline Morocco & 0.006 & 0.000 & 0.000 & 0.29 & 0 & 0.70 \\
\hline Mozambique & 0.000 & 0.000 & 0.000 & 0.48 & 0 & 0.22 \\
\hline Namibia & 0.000 & 0.000 & 0.001 & 0.35 & 0 & 0.47 \\
\hline Nepal & 0.000 & 0.000 & 0.000 & 0.32 & 0 & 0.51 \\
\hline Netherlands & 0.038 & 0.006 & 0.002 & 0.57 & 1 & 1.16 \\
\hline Nicaragua & 0.012 & 0.000 & 0.000 & 0.49 & 0 & 0.24 \\
\hline Niger & 0.000 & 0.000 & 0.000 & 0.21 & 0 & 0.11 \\
\hline Nigeria & 0.000 & 0.000 & 0.000 & 0.18 & 0 & 0.17 \\
\hline Pakistan & 0.000 & 0.000 & 0.000 & 0.24 & 0 & 0.21 \\
\hline Panama & 0.009 & 0.000 & 0.000 & 0.61 & 0 & 0.73 \\
\hline Paraguay & 0.000 & 0.000 & 0.000 & 0.54 & 0 & 0.30 \\
\hline Peru & 0.002 & 0.001 & 0.001 & 0.58 & 0 & 0.24 \\
\hline Philippines & 0.001 & 0.000 & 0.000 & 0.42 & 0 & 0.28 \\
\hline Poland & 0.025 & 0.000 & 0.001 & 0.54 & 1 & 0.48 \\
\hline Portugal & 0.096 & 0.007 & 0.008 & 0.85 & 1 & 1.56 \\
\hline Qatar & 0.000 & 0.000 & 0.000 & 0.43 & 0 & 0.42 \\
\hline Romania & 0.031 & 0.009 & 0.000 & 0.66 & 1 & 0.39 \\
\hline Russian Fed. & 0.000 & 0.000 & 0.000 & 0.39 & 0 & 0.40 \\
\hline Saudi Arabia & 0.000 & 0.000 & 0.000 & 0.4 & 0 & 0.38 \\
\hline Senegal & 0.000 & 0.000 & 0.000 & 0.33 & 0 & 0.24 \\
\hline Singapore & 0.000 & 0.001 & 0.000 & 0.59 & 0 & 0.91 \\
\hline South Africa & 0.004 & 0.003 & 0.002 & 0.21 & 0 & 0.72 \\
\hline Spain & 0.091 & 0.015 & 0.053 & 0.69 & 1 & 1.70 \\
\hline Sri Lanka & 0.001 & 0.000 & 0.000 & 0.65 & 0 & 0.24 \\
\hline Sudan & 0.000 & 0.000 & 0.000 & 0.42 & 0 & 0.10 \\
\hline Sweden & 0.143 & 0.001 & 0.001 & 0.56 & 1 & 1.20 \\
\hline Syria & 0.000 & 0.000 & 0.000 & 0.41 & 0 & 0.20 \\
\hline Tajikistan & 0.000 & 0.000 & 0.000 & 0.19 & 0 & 0.11 \\
\hline Tanzania & 0.000 & 0.000 & 0.000 & 0.48 & 0 & 0.15 \\
\hline Thailand & 0.000 & 0.003 & 0.000 & 0.61 & 0 & 0.92 \\
\hline Togo & 0.000 & 0.000 & 0.000 & 0.23 & 0 & 0.19 \\
\hline Trinidad \& Tobago & 0.000 & 0.000 & 0.000 & 0.71 & 0 & 0.34 \\
\hline Tunisia & 0.003 & 0.000 & 0.004 & 0.46 & 0 & 0.60 \\
\hline Turkey & 0.013 & 0.000 & 0.011 & 0.66 & 0 & 0.38 \\
\hline Ukraine & 0.002 & 0.001 & 0.000 & 0.52 & 0 & 0.63 \\
\hline
\end{tabular}




\begin{tabular}{lllllll}
\hline United Kingdom & 0.053 & 0.010 & 0.001 & 0.69 & 1 & 1.90 \\
United States & 0.052 & 0.009 & 0.009 & 0.63 & 1 & 0.52 \\
Uruguay & 0.052 & 0.001 & 0.000 & 0.68 & 0 & 0.21 \\
Vietnam & 0.000 & 0.000 & 0.000 & 0.53 & 0 & 1.00 \\
Zambia & 0.000 & 0.000 & 0.000 & 0.18 & 0 & 0.10 \\
\hline
\end{tabular}

